NBER WORKING PAPER SERIES

\title{
ECONOMIC POLICY UNCERTAINTY AND THE CREDIT CHANNEL: AGGREGATE AND BANK LEVEL U.S. EVIDENCE OVER SEVERAL DECADES
}

\author{
Michael D. Bordo \\ John V. Duca \\ Christoffer Koch \\ Working Paper 22021 \\ http://www.nber.org/papers/w22021 \\ NATIONAL BUREAU OF ECONOMIC RESEARCH \\ 1050 Massachusetts Avenue \\ Cambridge, MA 02138 \\ February 2016
}

We thank William D. Dupor, Leonardo Gambacorta, Joseph G. Haubrich, Michael Weiss, and seminar participants at the Federal Reserve Bank of Dallas, the 2015 Federal Reserve System Committee Meeting on Financial Structure and Regulation in Charlotte, NC, and the 2015 25th Annual Rome International Conference on Money, Banking, and Finance for suggestions. We also thank Tyler Atkinson, James B. Cooke, and Camden Cornwell for providing excellent research assistance. The views expressed are those of the authors and do not necessarily reflect the views of the Federal Reserve Bank of Dallas, the Federal Reserve System, or the National Bureau of Economic Research. Any remaining errors are those of the authors.

At least one co-author has disclosed a financial relationship of potential relevance for this research. Further information is available online at http://www.nber.org/papers/w22021.ack

NBER working papers are circulated for discussion and comment purposes. They have not been peerreviewed or been subject to the review by the NBER Board of Directors that accompanies official NBER publications.

(C) 2016 by Michael D. Bordo, John V. Duca, and Christoffer Koch. All rights reserved. Short sections of text, not to exceed two paragraphs, may be quoted without explicit permission provided that full credit, including $\odot$ notice, is given to the source. 
Economic Policy Uncertainty and the Credit Channel: Aggregate and Bank Level U.S. Evidence over Several Decades

Michael D. Bordo, John V. Duca, and Christoffer Koch

NBER Working Paper No. 22021

February 2016

JEL No. E40,E50,G21

\begin{abstract}
Economic policy uncertainty affects decisions of households, businesses, policy makers and Financial intermediaries. We first examine the impact of economic policy uncertainty on aggregate bank credit growth. Then we analyze commercial bank entity level data to gauge the effects of policy uncertainty on Financial intermediaries' lending. We exploit the cross-sectional heterogeneity to back out indirect evidence of its effects on businesses and households. We ask (i) whether, conditional on standard macroeconomic controls, economic policy uncertainty affected bank level credit growth, and (ii) whether there is variation in the impact related to banks' balance sheet conditions; that is, whether the effects are attributable to loan demand or, if impact varies with bank level financial constraints, loan supply. We find that policy uncertainty has a significant negative effect on bank credit growth. Since this impact varies meaningfully with some bank characteristics - particularly the overall capital-to-assets ratio and bank asset liquidity-loan supply factors at least partially (and significantly) help determine the influence of policy uncertainty. Because other studies have found important macroeconomic effects of bank lending growth on the macroeconomy, our findings are consistent with the possibility that high economic policy uncertainty may have slowed the U.S. economic recovery from the Great Recession by restraining overall credit growth through the bank lending channel.
\end{abstract}

Michael D. Bordo

Department of Economics

Rutgers University

New Jersey Hall

75 Hamilton Street

New Brunswick, NJ 08901

and NBER

bordo@econ.rutgers.edu

John V. Duca

Federal Reserve Bank of Dallas

2200 North Pearl Street

Dallas, TX 75201

John.V.Duca@dal.frb.org
Christoffer Koch

Federal Reserve Bank of Dallas

2200 North Pearl Street

Dallas, TX 75201

Christoffer.Koch@dal.frb.org 


\section{Introduction}

Recent literature emphasizes how uncertainty matters for economic decision-making. For example, Stokey (2008) devotes an entire book to theoretically analyzing "[T]he Economics of Inaction." Bloom (2009) develops a tractable model in which uncertainty results in a central region of inaction for hiring and investment, with this zone of inaction expanding when uncertainty is higher because nonconvex adjustment costs increase. Recently, new methodologies have enabled researchers to better measure macroeconomic (Jurado, Ludvigson, and Ng, 2015) and economic policy uncertainty (Baker, Bloom, and Davis, 2015). And at the macro-level, Karnizova and Li (2014) find that economic policy uncertainty helps predict recessions in the presence of now-standard financial variables. Less well explored are the more specific channels through which economic policy uncertainty may affect the macro economy.

This is particularly the case with the recent weak recovery of U.S. bank lending, as evidenced by a lower path of real total bank loans following the Great Recession than in earlier recessions since 1969-70 (Figure 1). Following the Great Recession, bankers complained that delays implementing financial reform under the Dodd-Frank Act created regulatory policy uncertainty (Koch, 2012) that restrained lending, which, in turn, slowed the economic recovery. Indeed, three years after DoddFrank became law, rule-writing regulatory agencies set only about one-half of the new regulations and reporting requirements have continued to increase (Figure 2). At the same time, the index of economic policy uncertainty (EPU) based on newspaper wording ("EPU index", Baker, Bloom, and Davis, 2015) had been at elevated levels during the Great Recession and the early part of the economic recovery, generally exceeding the cyclical averages seen in the first four years following the onset of the five prior recessions (Figures 3 and 4$){ }^{1}$

These developments naturally raise the questions: Did economic policy uncertainty restrain U.S. bank lending during the prolonged recovery from the Great Recession and what role has it played in other periods? To address these issues, we analyze data for the banking industry in its entirety and individual banks separately to empirically assess whether the EPU index contains

\footnotetext{
${ }^{1}$ The index measures the number of articles that include the words (1) 'uncertain' or 'uncertainty', and (2) 'economics', 'economy', 'business', 'commerce', 'industry', or 'industrial', and (3) 'Congress', 'legislation', 'White House', 'regulation', 'Federal Reserve', or 'deficit'. Source: http://www.policyuncertainty.com/us_historical. html.
} 
marginal information about the growth of bank lending, controlling for variables ranging from interest rates and GDP growth to controls for early regulations that affected the bank lending decisions such as Regulation Q (Aron, Duca, Muellbauer, Murata, and Murphy, 2012; Koch, 2015) and the credit controls of 1980. We exploit the cross-sectional heterogeneity to back out indirect evidence of EPU's effects on bank lending. We ask (i) whether, conditional on standard macroeconomic controls along with ones for regulation, did economic policy uncertainty affect bank level credit growth, and (ii) whether there is variation in the impact related to banks' balance sheet conditions, i.e., whether the effects are attributable to loan demand or, if the impact varies with bank level financial constraints, reflect individual bank loan supply effects.

We find that policy uncertainty significantly slows U.S. bank credit growth, consistent with it having an effect on broad loan supply and demand. We find that lagged changes in the EPU index are negatively and significantly linked to the growth rate of bank lending both at the aggregate and cross-sectional levels. For the latter, we construct a bank level data set from call reports that has commonly been used in bank level studies of the credit channel of monetary transmission, see, for instance, Kashyap and Stein (2000), Kishan and Opiela (2000), Ashcraft (2006) or Bluedorn, Bowdler, and Koch (2014).

Using aggregated data, economic policy uncertainty is highly significant in quarterly models of real per capita bank loan growth spanning 1961 to 2014. This result is robust to the inclusion or exclusion of macroeconomic controls (lags of GDP growth and changes in the real fed funds rate), direct regulatory controls (a measure of the effects of deposit regulations and an episode when the Federal Reserve implemented credit controls in 1980), lags of the forward-looking (expectations) index of consumer sentiment from the University of Michigan, and other macro variables which may be correlated with economic policy uncertainty. We also find that innovations to EPU also have significant effects on GDP and bank loans in VARs, consistent with the battery of VARs of Baker, Bloom, and Davis (2015) who do not focus on bank lending.

A robust impact of EPU on loan growth also arises when individual bank data are analyzed in models that use a general specification better suited to cross-sectional data. The cross-section enables us to more convincingly identify a role for loan supply factors by examining how individual 
bank asset characteristics are linked to the impact of economic policy uncertainty.

In particular, three statistically and economically meaningful results arise using relative indexes of individual bank asset characteristics. First, the negative effects of economic policy uncertainty (EPU) on loan growth are greater for larger-sized banks. One explanation for the size effect is that it may reflect a greater importance of national uncertainty for larger banks that tend to be more geographically diversified than smaller banks. Second, the negative effect of economic policy uncertainty on bank lending growth is smaller in magnitude for more highly capitalized banks. This suggests that the shock-absorbing buffer effects of greater capitalization that tend to reduce economic policy uncertainty effects outweigh the potential offsetting selection effects, the latter of which reflect that higher capitalization rates could be associated with greater risk aversion among banks. ${ }^{2}$ Third, the depressing effect of economic policy uncertainty on bank lending is significantly but quantitatively only somewhat smaller at banks with more cash assets, with no significant correlation with differing levels of securities holdings. These three results are robust to the inclusion or exclusion of different control variables (e.g., lagged GDP growth, changes in the real federal funds rate, deposit rate and credit controls, and consumer sentiment).

The results have several important implications. First, statistical evidence suggests that economic policy uncertainty has affected bank lending in the U.S., which other studies have found to have important effects on economic activity and which we also find. This could have implications for Europe, where the Baker-Bloom-Davis (BBD) index of economic policy uncertainty rose more than in the U.S. during the post-crisis slump (Figure 5) and the economies are more bank dependent. More recently, the EPU index in Europe has not recovered as quickly as in the U.S., where the subsequent recovery in bank-lending growth has been stronger as has been the overall recovery in GDP growth. Second, we find that the national economic policy uncertainty is associated with larger declines in bank loan growth at larger U.S. banks, weakly capitalized banks, and at banks holding less cash. This provides evidence of loan supply side-effects at the level of individual banks and suggests somewhat mixed evidence of the impact of recent financial reforms. On the one hand,

\footnotetext{
${ }^{2} \mathrm{~A}$ priori, the negative impact of economic policy uncertainty on bank lending could be greater at more riskaverse banks that to be better capitalized. Well-capitalized banks may be more risk-averse because the implicit subsidy from deposit insurance is a decreasing function of capital (Flannery, 1989; Gennotte and Pyle, 1991) or because they want to reduce the probability of not meeting capital requirements (Dewatripont and Tirole, 1994).
} 
higher capitalized banks and to a lesser extent those with more cash tend to reduce lending less in response to greater economic policy uncertainty, but on the other hand, the effects do not significantly differ in magnitude across banks with differing portfolio shares in securities. Together, these empirical findings that economic policy uncertainty affects financial flows via a bank lending channel are consistent with the view (1) that the elevated levels of economic policy uncertainty that often accompany recessions and periods of slow economic growth have contributed to weak bank loan growth, and (2) that the implications of financial reforms for financial stability should be evaluated from a holistic perspective.

Furthermore, our findings suggest that the initial announcement or implementation effects of stricter liquidity and capital requirements on banks likely muted the depressing effects of policy uncertainty associated with the post-crisis slump. Because other studies have found important macro-economic effects of bank lending growth on the macro-economy, this may help account for the delayed and weak recovery of U.S. bank loan growth following the Great Recession and is consistent with more recent signs of an upturn in bank lending that has followed the recent decline of U.S. economic policy uncertainty to levels predating the Great Recession and the transition to a more highly capitalized banking system.

To establish these findings, the study is organized along the following lines. Section 2 lays out the specifications used to analyze U.S. bank loan growth at the national and individual bank levels, while Section 3 briefly describes the data and variables. Section 4 presents the empirical results for the U.S., Section 5 highlight important robustness checks and Section 6 examines the impact of EPU on bank credit standards to help gauge the macroeconomic impact of EPU. Section 7 concudes by discussing and interpreting their implications.

\section{Empirical Specifications}

The empirical analysis employs a combination of aggregate and bank level auto-regressions of real bank loan growth, using quarterly data back to 1961. The main sets of regressions use the historical, newspaper version of the BBD EPU index that is available over a longer sample period. The models of disaggregated loan growth are able to incorporate some bank-level characteristics 
and examine how the sensitivity of loan growth at individual banks is associated with different aspects of bank balance sheets.

\subsection{Empirical Specification for Aggregate Loan Growth}

The baseline specification for total aggregate bank loans is:

$$
\Delta \ln L_{t}=\alpha+\sum_{\ell=1}^{n} \rho_{\ell} \Delta \ln L_{t-\ell}+\sum_{\ell=1}^{n} \beta_{\ell} \mathrm{M}_{t-\ell}+\sum_{\ell=1}^{n} \gamma_{\ell} \mathrm{EPU}_{t-\ell}+\varepsilon_{t}
$$

Aggregate level quarter-over-quarter real per capita growth in bank loans held in portfolios is regressed on a constant, its own lags $\Delta \ln L_{t-\ell}$ (throughout the paper lags are indexed by the subscript $\ell$ ), macroeconomic and regulatory controls $\left(\mathrm{M}_{t}\right)$, and economic policy uncertainty (EPU). Macroeconomic controls include the growth rate of real GDP and the change in the real federal funds rate (defined using the year-over-year smoothed GDP inflation rate). Regulatory controls include (1) a dummy for quarter when credit controls were in effect in 1980 and (2) Duca and Wu's (2009) measure of how binding Regulation Q ceilings were on time deposit interest rates at

banks. The specification also includes quarterly dummies to capture lending seasonality and a time-trend. The expected conditions index of consumer sentiment from the Michigan index was used to control for the expected economic outlook in some empirical models. 


\subsection{Empirical Specification for Bank Level Loan Growth}

Following the literature on the lending channel, we estimate specification (2) across a panel of U.S. commercial banks (denoted by subscript $i$ ):

$$
\begin{aligned}
\Delta \ln L_{i, t}= & \alpha+\sum_{\ell=1}^{4} \rho_{\ell} \Delta \ln L_{i, t-\ell}+\sum_{\ell=1}^{4}\left(\mu_{1, \ell} \Delta y_{t-\ell}+\mu_{2, \ell} \Delta R F F_{t-\ell}^{\text {real }}+\mu_{3, \ell} \text { EPU }_{t-\ell}\right) \\
& +\delta_{1} \cdot \text { Assets }_{i, t-1}+\delta_{2} \cdot \text { Equity }_{i, t-1} \\
& +\delta_{3} \cdot \text { Cash }_{i, t-1}+\delta_{4} \cdot \text { Securities }_{i, t-1} \\
& +\sum_{\ell=1}^{4}\left(\tau_{1, \ell} \cdot \text { Assets }_{i, t-1} \cdot \text { EPU }_{t-\ell}+\tau_{2, \ell} \cdot \text { Equity }_{i, t-1} \cdot \text { EPU }_{t-\ell}\right) \\
& +\sum_{\ell=1}^{4}\left(\tau_{3, \ell} \cdot \text { Cash }_{i, t-1} \cdot \text { EPU }_{t-\ell}+\tau_{4, \ell} \cdot \text { Securities }_{i, t-1} \cdot \text { EPU }_{t-\ell}\right) \\
& + \text { other controls }+\varepsilon_{i, t}
\end{aligned}
$$

where annualized quarter-over-quarter real loan growth at bank $i$ in percentage points is regressed on a constant, its own lag $\Delta L_{i, t-1}$, macroeconomic controls such as the quarterly growth rate of GDP $\Delta y_{t l}$, and the quarterly change in the real federal funds rate $\Delta R F F_{t-1}^{r e a l}$. We also include a time-trend, quarterly dummies, and bank specific quarterly dummies as controls commonly used in the literature: Assets denotes appropriately normalized total bank assets, Equity denotes capital-ratios, Cash is the cash plus reserves ratio, and Securities denotes the securities-ratio. The balance sheet ratios are demeaned within quarter and normalized within quarter by dividing them by one standard deviation. In contrast, the bank size variable is first transformed to an integer denoting its within-quarter-size percentile. We then subtract 50, so the integer is between -49 and 50, and then divide by one hundred. Thus, a zero entry designates a bank at the size median in the respective quarter, 0.50 a bank in the top asset size percentile within the quarter and -0.49 for the smallest banks in the bottom asset size percentile in the respective quarter. To ensure that our results are not driven by other macroeconomic or regulatory variables, we include such macro variables and regulatory variables in several robustness checks. To test for the effect 
of any particular macro variable, we report tests on several null hypotheses:

$$
H_{0}: \sum_{\ell=1}^{4} \mu_{k, \ell}=0 \quad \text { with } \quad k=1,2,3
$$

In order to understand how the impact of economic policy uncertainty varies with bank level proxies for financial constraints, we test:

$$
H_{0}: \sum_{\ell=1}^{4} \tau_{k, \ell}=0 \quad \text { with } \quad k=1,2,3,4
$$

taking into account level heterogeneity across the respective characteristics via the parameters $\delta_{k}$ in specification (2).

\section{Data and Variables}

This section describes the (i) economic policy uncertainty variable, macroeconomic and regulatory controls, and (ii) entity level data underlying the subsequent empirical analysis.

\subsection{Economic Policy Uncertainty}

We employ three indexes of economic policy uncertainty $(E P U)$ constructed by Baker, Bloom, and Davis (2015). The first is their historical, newspaper based index that measures the frequency of references to economic uncertainty and policy in leading newspapers. From 1900 to 1984, the index is based on six newspapers and in 1985 expanded to cover four additional newspapers, with break adjustments for changes in the composition of newspapers in their index. ${ }^{3}$ Examining the information content of the historical series enables us to analyze a long time series on bank lending extending back to 1961 that covers a number of business, interest rate, and credit cycles.

As a robustness check on our findings for the longer-sample historical series, we also examine two other EPU indexes of Baker, Bloom, and Davis (2015) that cover the shorter sample period of 1985 to present. These are their new overall EPU index (EPU1985) and a component of it that covers uncertainty regarding finance (EPUFin)-including monetary policy and financial

\footnotetext{
${ }^{3}$ The six original newspapers are the Boston Globe, the Chicago Tribune, the Los Angeles Times, the New York Times, the Wall Street Journal, and the Washington Post. The four additional newspapers are the Dallas Morning News, the Miami Herald, the San Francisco Chronicle, and USA Today.
} 
regulation. The appeal of analyzing EPU1985 is that it is a more comprehensive measure of economic policy uncertainty than the newspaper based historical series. Nevertheless, these series are highly correlated since 1985. The advantage of assessing the information content of their financial EPU index (EPUFin) is that this index focuses on the sort of uncertainty that intuitively would affect bank lending more-interest rates and financial regulation-and is less prone to reflecting endogenous, general business cycle factors that may be correlated with more general measures of economic policy uncertainty.

\subsection{Macroeconomic and Regulatory Variables}

The macroeconomic data that we employ in our analysis include several types of variables. To deflate aggregate bank loan levels, we use the GDP chain price deflator. Nonregulatory factors are captured by including lags of real GDP growth $(\Delta y)$ and the change in the real federal funds rate $(\triangle R F F$, defined using Hodrick-Prescott filtered year-over-year percent change in the implicit GDP price deflator). Our measure of the real federal funds rate does account for the zero lower bound by setting the nominal federal funds rate equal to the $\mathrm{Wu}$ and Xia (2014) shadow federal funds rate after policy rates hit the zero bound. Some empirical models include two variables to control for regulatory induced effects on bank lending. One is a measure $(\operatorname{Reg} Q)$ of how binding Regulation Q deposit ceilings were on banks (Duca and $\mathrm{Wu}, 2009$ ) to control for built-in regulatory drags on lending growth in an era (pre-1984) when loan securitization markets were too poorly developed to offset Regulation Q induced disintermediation. The other is a dummy for the Carter credit controls of early 1980 (CCon $=1$ from March to June 1980), which induced banks to sharply curtail lending growth and provoked a sharp recession, before the controls were removed in mid-1980. Because such regulations have not occurred in the U.S. since 1983, including RegQ and CCon helps control for pre-1983 regime shifts in the longer sample used in the aggregate level models. A final variable-the percent change in the expectations component of the University

of Michigan's Index of Consumer Sentiment $(\Delta C$ onf Exp) regarding the future (the expectations index)-we found outperformed lags of the slope of the Treasury yield curve and the percent change in the index of leading economic indicators. 


\subsection{Bank Level Data}

We construct a bank level data set from regulatory filings, the Report of Income and Conditions (call reports), commonly used in bank level studies of the credit channel of monetary transmission (Kashyap and Stein, 2000; Kishan and Opiela, 2000; Ashcraft, 2006; Bluedorn, Bowdler, and Koch, 2014). We construct entity level measures of bank size by assets (call report variable $\operatorname{rcfd} 2170$ ), capitalization (rcfd3210), liquidity composed of cash (rcfd0010) and securities (currently rcfd1754 and rcfd1773; see the footnote for historical details). ${ }^{4}$ We restrict the sample to insured commercial banks. ${ }^{5}$ We also remove banks that had been involved in a merger in the previous four quarters. The data span more than 50 years of entity level data, from 1961 Q4 to 2014 Q3. Bank $i$ assets (Asset) are normalized within each quarter, to be uniformly distributed between -0.49 and +0.5 ; this was done by assigning each bank a percentile ranking, subtracting 50, and then dividing by 100. The bank balance sheet ratios for capitalization (bank capital divided by unweighted total assets, Equity), the asset portfolio share of bank reserves and cash (Cash) and that of securities (Securities) were normalized by subtracting the within-quarter mean and dividing by the withinquarter standard deviation. The last two interactive terms allow for the sensitivity of bank loan growth to economic policy uncertainty to vary with the relative liquidity of assets across banks.

\section{Results from Modeling U.S. Bank Loan Growth}

We first review findings from modeling aggregate bank lending, which has the appeal of internalizing substitution or shifts in lending among banks. Then, results from bank level specifications are reviewed, which have the advantage of offering stronger evidence of loan supply shift identification and limiting observational equivalence by drawing upon individual bank characteristics that likely proxy for bank level financial constraints. We remove banks involved in mergers in the prior four quarters. In order to deal with other exceptional movements in the data, we follow Ashcraft (2006) and Bluedorn, Bowdler, and Koch (2014) in fitting all regressions through OLS for the

\footnotetext{
${ }^{4}$ Between 1985 Q1 and 1993 Q4 we use rcfd0390, after 1993 Q4 we sum rcfd1754 and rcfd1773 to construct security holdings.

${ }^{5}$ That is those entries for which the charter type code (rssd9048) is 200 or 340 and the primary insurer code $(\operatorname{rss} d 9424)$ is $1,2,6$ or 7.
} 
largest possible sample and then eliminating outliers. These are defined as observations for which the absolute DFITS statistic (the scaled difference between the fitted values for the $\mathrm{n}^{\text {th }}$ observation when the regression is fitted with and without the $\mathrm{n}^{\text {th }}$ observation) exceeds the threshold $2 \sqrt{\frac{N}{K}}$, where $K$ is the total number of explanatory variables and $N$ is the overall sample size (Welsch and Kuh, 1977).

\subsection{Aggregate Level Results, 1961 - 2014}

Results from quarterly models of aggregate, real per capita bank loan growth spanning 1961 Q4 to 2014 Q3 are summarized in Table 1, which reports sums of coefficients on lags of EPU and the standard errors for each of those sums in the first row. Estimated coefficients are multiplied by 100 so that coefficients represent the loan growth response in terms of basis points. Four models are presented, starting with a baseline model (Model 1), which only includes lags of loan growth and EPU. Model 2 also includes lags of changes in the real federal funds rate and real GDP growth ("nonregulatory controls"), to which Model 3 adds the lagged deposit regulation $(\operatorname{Reg} Q)$ and the credit control variable (Ccon), and to which, in turn, Model 4 also adds lags of the Michigan index of consumer sentiment expectations. ${ }^{6}$ These models are estimated for four categories of bank loans, reported in the rows across Table 1 in the following order: total, commercial and industrial $(\mathrm{C} \& \mathrm{I})$, real estate, and consumer loans. For each model, the Akaike Information Criterion is used to choose the common lag length on included variables.

In each of the four models presented for total loan growth, sums of coefficients on lags of EPU are jointly significant and negative, indicating a near term depressing effect of economic policy uncertainty. For total loan growth, this result is robust to including no controls (column 1), two macro controls (lags of real GDP growth and changes in the real fed funds rate, in column 2), macro and regulatory controls (a measure of Regulation Q effects and a dummy for the Carter credit controls of 1980, in column 3), and additionally lags of the forward-looking (expectations) index of consumer sentiment (column 4). Lags of the change in the real federal funds rates and those of the deposit regulation and credit control variables were jointly statistically significant,

\footnotetext{
${ }^{6}$ This index easily outperformed the insignificant slope of the Treasury yield curve and the percent change in the index of leading economic indicators.
} 
with estimated negative effects, while lags of consumer sentiment were positively and significantly correlated with loan growth.

The estimated effect appears to work primarily through commercial and industrial loans. As shown in the second row set of results in Table 1, these qualitative and significant results hold up for C\&I loans across all four models. However, the impact of EPU on the particular categories of real estate and consumer loan growth is generally insignificant, perhaps reflecting the greater volatility of consumer loans and the longer maturity of real estate loans. The last characteristic which would tend to make the growth rate of the stock of real estate loans less reflective of recent conditions than shorter-lived business loans whose loan interest rates also tend to be indexed to short-term interest rate benchmarks more than real estate loans.

\subsection{Bank Level Results, 1961 - 2014}

We find substantial heterogeneity in the effects of economic policy uncertainty on different commercial banks. Results from quarterly models of bank level loan growth spanning 1961 Q4 to 2014 Q3 are summarized in Table 2, which presents results from four sets of two models that parallel the four models in Table 1 for total loans. We present a lag length of four quarters, consistent with most cross-section studies of bank lending, as the common lag length on included variables. Table entries report the estimated joint coefficients on the different lags of each variable with the standard error in parentheses. Models 1 and 2 have no extra controls, with Model 2 differing by also including interactions of EPU with the relative ranking of banks by asset size, normalized capitalization, cash share of assets, and the securities' share of assets. The second set of models (3 and 4) adds lagged real GDP growth rates and changes in the real funds rate, to which the third set (models 5 and 6) add lags of the Regulation Q and credit control variables and to which, in turn, the fourth set of models adds the expectation component of the Michigan sentiment index. In each set, the even numbered model includes the four interactive terms, which are omitted from the odd-numbered model.

Comparing across each row of Table 2 reveals a robust pattern of results. For example, the first row indicates a significant and negative impact of EPU lags with coefficients (multiplied by 100) in 
a reasonably similar range, varying between -2.6 and -4.3 . The second row reports estimates from models that explore how these effects relate to bank size. The negative effect of policy uncertainty is greater in magnitude for larger banks and less in magnitude for smaller banks. This is evidenced by a negative and significant coefficient on the variable interacting EPU, with an indicator of relative bank asset size (Assets reflects the percentile ranking of each bank's asset size in each quarter) in the second row.

To interpret the coefficients, recall that bank $i$ assets are normalized within each quarter to be uniformly distributed between -0.49 and +0.50 (done by assigning each bank a percentile ranking, subtracting 50, and then dividing by 100). So the coefficients in the right-most column of Table 2 imply that a one hundred point increase in the EPU index, over the course of four quarters, would reduce the level of lending by the largest banks in the 100th percentile by -4.2 percentage points $(\approx-3.17+(-1.81 \times 0.50))$, whereas the smallest banks in the 1 st size percentile would only see a $2.3(\approx-3.17+(-1.81 \times-0.49))$ percentage point fall in lending growth. One explanation for the size effect is that it may reflect greater importance of national uncertainty for larger banks that tend to be more geographically diversified than smaller banks.

The impact of greater capitalization and higher asset-side liquidity with the sensitivity of loan growth to EPU are highlighted by the third through fifth rows of Table 2. Regardless of the controls, the variable interacting EPU with a bank's normalized level of capitalization (third row) is significant and positive, working to partially offset the direct negative and significant effect of the sum of coefficients on the non-interacted EPU lags in the first row of Table 2. This pattern implies that the negative impact of $E P U$ on bank loan growth is significantly smaller as bank capitalization increases, consistent with the positive capital buffer effect outweighing any negative selection and the reduced risk-taking incentive effects of higher capitalization. For example, the coefficient in the third row, right-most column of Table 2 implies that the impact of EPU on the median-sized bank is -3.17 b.p. with the effect being 0.63 smaller (larger) in size for the banks one standard deviation above (below) the quarterly cross-sectional mean in terms of their capitalization.

The role of balance sheet liquidity depends on its type - cash and securities play very different roles, a fact consistent with findings in Bluedorn, Bowdler, and Koch (2014). The variables inter- 
acting EPU with a bank's rank by asset liquidity are mixed, with the interaction of EPU with Cash being significant and positive and that with Securities being statistically insignificant, as reported in the fourth and fifth rows of Table 2, implying that the negative impact of EPU on bank loan growth is significantly smaller as the cash share of a bank's assets increases. We find a shielding effects from cash, but not from securities holdings. For example, the coefficients in the right-most column of Table 2 imply that the impact of EPU on the median-sized bank is -3.17 b.p. with the effect being 0.25 b.p. smaller (larger) for the banks one standard deviation above (below) the cross-sectional mean in terms of cash as a share of total assets.

Table 2 also provides detail on the effects of other variables for these models, finding significant and positive effects of real GDP growth along with significant and negative expected effects of changes in the real funds rate, the degree to which Regulation $\mathrm{Q}$ was binding, and the credit controls of 1980. We emphasize that these effects are robust to the inclusion of consumer sentiment, which has a highly significant and positive coefficient in both models 7 and 8 . The robustness of the bank level findings for total loan growth was assessed for the three large loan categories of C\&I, real estate, and consumer loans using the same eight model specifications of Table 2. To conserve space, Table 3 reports the findings for EPU and its interactions with bank-specific balance sheet variables.

Three general patterns are revealed in Table 3. First, a significant and negative impact of EPU lags is consistently observed across all the models for each loan category. Second, the qualitative findings for balance sheet interactions are maintained for three of the four types of variables: EPU has stronger negative effects on larger-sized banks and less negative effects on banks that are either more highly capitalized or have higher portfolio shares in cash. Third, the insignificance of EPU interacted with banks' portfolio holdings of securities holds up for C\&I and consumer loans, but $E P U$ has significantly less negative effects on real estate lending for banks with greater securities holdings (the interactive effect is significantly positive). This slight difference may arise because a more liquid portfolio may induce banks to adjust their holdings of long-maturity real estate holdings less in response to higher economic policy uncertainty.

Although the estimated effects of EPU on bank total loan growth are statistically significant, 
it is unclear how economically meaningful these effects are from Tables 1 and 2 alone. To gauge this, we conduct two exercises which measure the extent to which economic uncertainty exceeded its pre-crisis level of 101.9 in 2007 Q2, just before the turbulence that began in August 2007 when several hedge funds froze redemptions on subprime-related investments. As shown in Table 4, EPU averaged 81.0 index points above its 2007 Q2 level from 2007 Q4 to 2011 Q4, 83.1 index points above that level from 2007 Q4 to 2012 Q4, and 80.7 index points above that level from 2007 Q4 to 2013 Q4. Using the estimated effect of EPU on the median bank with average characteristics (Model 8 in Table 2) implies that since the start of the Great Recession (2007 Q4), the high levels of EPU have lowered quarterly, real annualized loan growth by an average of 2.6 percentage points in each of these periods, as reported in the middle column of Table 3.

These figures may actually understate the effect during the current recovery because banking concentration has increased substantially in recent decades (Fernholz and Koch, 2016). During the recovery about one-half of the banking system's assets were held at the four largest banks. The estimates from Model 8 indicate a stronger negative effect of $E P U$ on loan growth at banks in the top percentile of asset size. As discussed earlier and from inspection of row 2 in Table 3 the net EPU effect on them equals the -3.17 plus $(0.5 \times-1.81)$ for a total of about -4.2 . Weighting marginal increase due to bank size by 50 percent and the median figure by 50 percent implies a weighted average EPU effect of about -3.62. As shown in the right-most column of Table 4, this value implies that since the start of the Great Recession (2007 Q4), the high levels of EPU and combination with the very concentrated bank assets at few large banks have lowered quarterly, real annualized loan growth by an average of 2.9 percentage points through 2011 Q4, 3.0 percentage points through 2012 Q4, and 2.9 percentage points through 2013 Q4. These impacts are large relative to actual real per capita loan growth, which averaged near 0.5 percent in the last period and a shade below zero percent during the first two of these periods. Our back-of-the-envelop illustration from Table 4 and our broader historical findings are in line with recent research that focuses on very specific effects of financial regulatory uncertainty in the aftermath of the Great Recession for instance on "qualified mortgages" as in Gissler, Oldfather, and Ruffino (2016). 


\section{Robustness Checks Using Post-1984 Economic Policy Uncertainty Series}

This section discusses three types of robustness checks. The earlier sections used BBD's historical, news-based series. This section presents results from re-estimating the aggregate and bank level models replacing the historical news-based EPU series first with BBD's post-1984 total measure of EPU (EPU1985) and secondly with the post-1984 economic policy uncertainty component that reflects uncertatinty regarding the financial sector (EPUFin). In addition, these findings are provided for total, C\&I, real estate, and consumer loans.

\section{$5.1 \quad$ Aggregate Level Results, 1985 - 2014}

Results from quarterly models of aggregate, per capita bank loan growth spanning 1985 Q4-2014 Q3 are summarized in Table 5, which reports sums of coefficients on lags of EPU1985 or EPUFin and the standard errors for each of those sums in the first row. Estimated coefficients on EPU1985 and EPUFin are multiplied by 100 to normalize them. Models 1, 2, and 4 are repeated from Table 1 and appear as Models 1-3 for the models using EPU1985 and 4-6 for the models using EPUFin, respectively. Because the shorter sample occurs after deposit deregulation and the 1980 credit controls, Model 3 from Table 1 corresponds to Models 2 and 5 in Table 5 and Model 4 from Table 1 corresponds to the post-1984 versions of Models 3 and 6 in Table 5, except that the Table 5 models omit the two regulatory variables. Another difference from Table 1 is that the results are now reported for four categories of loans: total, C\&I, real estate, and consumer. Generally mirroring the results using the historical EPU series, lags of the post-1984 overall and financialsector oriented EPU series have statistically significant and negative effects on aggregate level, total loan growth, but generally insignificant effects on the three major loan categories. The EPU series focusing on financial policy uncertainty tended to have effects on total loan growth that were statistically more significant than the overall EPU series, reflecting much smaller standard errors. This finding suggests that policy uncertainty effects on bank lending likely emanate from more financial-related uncertainty rather than reflecting a more general sense of uncertainty which 
could be more endogenous to the general business cycle.

\subsection{Bank Level Results, 1985 - 2014}

Bank-level variants of models 1-3 from Table 5 with and without the same set of four interactions of EPU and bank balance sheet characteristics from Table 2 are presented in models 1-6 in Table 6, where the EPU variable is the new, broader based BBD series (EPU1985). In the table, only coefficients are reported on EPU variables to conserve space, and the models are presented in four blocks corresponding to total, C\&I, real estate, and consumer loans. Table 7 mirrors Table 6 except that it reports results from models replacing EPU1985 with the financial economic policy uncertainty index, EPUFin. These models are estimated with data spanning 1985 Q1 to 2014 Q3, where the end of the sample corresponds to the availability of the historical news-based EPU series. (Estimating with data through 2015 Q2 yielded similar results).

Three general patterns arise across the models in Table 6. First, as with the historical EPU series, across all models and for each loan category, lags of EPU1985 have negative effects that are jointly significant, while this variable's interaction with the relative capital position of a bank has a positive sign-indicating that EPU has less negative impact on better capitalized banks. Second, while the interaction of bank asset size with EPU has a negative and jointly significant effect for total, real estate, and consumer loans, the variable is significant with the opposite signed effect for C\&I loans. Third, in contrast to the historical EPU series that is estimated over a longer sample with an earlier start date, the interaction of EPU1985 with the variable tracking the relative size of securities in bank balance sheets is significant and positive using EPU1985, whereas it was insignificant for models using the historical EPU series.

The patterns of results in Table 7 using EPUFin more closely match those reported earlier for using the historical EPU index in several ways. First, lags of EPUFin are jointly significant with negative effects in every model. Second, for every loan type and in each model, the interaction of EPUFin with bank asset size tends to reinforce the negative effect of EPU on lending, while the lags of the the interaction of EPUFin with a bank's capital position continue to have a significant and positive coefficient. These results indicate that financial economic policy uncertainty has larger 
negative effects on bank loan growth at larger and less-well capitalized banks. Third, the negative impact of EPUFin is smaller at banks with larger security holdings (the interactive variable has a positive sign), but this effect is not robust across all models and for every major loan category assessed. The interaction of EPU with cash holdings continued to be generally insignificant, once again mirroring the qualitative pattern of findings using the historical newspaper-based EPU series.

\section{Economic Policy Uncertainty and Bank Credit Stan- dards}

To examine EPU's links to bank lending and the macroeconomy, we review two types of evidence. In particular, we analyze the overall impact of historical, newspaper-based EPU shocks in a VAR and then try to gauge its effects on GDP by relating EPU to the VAR results of Bassett, Chosak, Driscoll, and Zakrajšek (2014) who assess the impact of changes in bank lending standards on GDP.

The impact of EPU innovations is examined in a quarterly VAR which contains, in the following order, shocks to GDP, the GDP price deflator, the nominal federal funds rate, aggregate bank loans, and EPU. While Baker, Bloom, and Davis (2015) also analyze the impact of EPU shocks on GDP in a VAR, the exercise here also examines the bank lending channel. A lag length of 4 is chosen and the model is estimated over 1965 Q1 - 2014 Q3. Figure 6 depicts the impact of a one-standard deviation shock to $E P U$, with peak effects on GDP and bank loans after five and nine quarters, respectively. A one-standard deviation shock to EPU (about 20 index points) lowers GDP by a peak effect of about 0.25 percentage point - broadly consistent with the Baker, Bloom, and Davis's (2015) findings - and reduces bank loans by as much as 0.5 percentage point on average - which is consistent with other results presented below. Between 2007 and 2010, the EPU index rose by about 80 index points - roughly four times a standard deviation shock to the index. Because some of this 80 point swing is endogenous to other factors in the VAR, it implies an upper limit of one and two percentage point respective declines in real GDP and bank loans. Of course these estimated effects on GDP include all the channels through which EPU innovations affect aggregate 
output.

To gauge how much may be through the bank lending channel, we draw on Bassett et al. (2014), who estimate the impact of a diffusion index $(D I)$ of changes in bank lending standards on GDP, finding that variation in this index accounts for about 20 percent of the variation in GDP between 1991 and 2012 in a VAR framework. Their index of overall credit standards weights bank survey responses about changes in credit standards on different loan types-business, consumer, and real estate (residential and commercial)-by the size of loans on bank balance sheets from Call Reports. Their series (Figure 7) indicates that credit standards were tightened in the early 2000s and during the recent housing and financial crisis period. Relevant to our study is whether EPU helps determine changes in overall bank lending standards as tracked by the Bassett et al. (2014) DI measure.

The limited structural evidence on what drives bank credit standards indicates that the determinants suggested by theory are likely to have a contemporaneous rather than a leading effect, leading some to estimate such effects and then remove them from an index of credit standards (e.g. Aron et al., 2012). In screening models of credit, such as that of Stiglitz and Weiss (1981), credit standards should be tightened when the real riskless rate rises and the macroeconomic outlook worsens. Following Aron et al. (2012), we track the former with the first difference of the real federal funds rate $(\triangle R F F)$, the nominal federal funds rate accounting for the zero lower bound as discussed earlier using $\mathrm{Wu}$ and Xia's (2014) shadow funds rate, minus the HP-filtered chain price GDP deflator, and the latter with the two-quarter percent change in the index of leading economic indicators $\left(\Delta_{2} L E I\right)$ in our model of the diffusion index of changes in credit standards. We include three other variables to control for factors affecting loan quality and risk. The first is the spread between three-month interest rates on financial commercial paper and Treasury bills $(C P T R)$, which may reflect near-term risk premia for both making and funding bank loans-a variant of Friedman and Kuttner's (1998) paper-bill spread. The other two variables track loan quality at banks and are the year-over-year change in the overall delinquency rate on bank loans $\left(\Delta_{4} D E L\right.$, Federal Reserve Board) and the $t-1$ lag of the two-quarter change in the home mortgage foreclosure rate $\left(\Delta_{2} M F\right.$ ore $)$, where the extra lag reflects that foreclosure data are released with a 
longer lag. Since each of these three reflects greater risk or incidence of problem loans, they are expected to be positively related to a gauge reflecting tightening bank credit standards, such as $D I$. To these we add contemporaneous EPU:

$$
D I_{t}=\beta_{0}+\beta_{1} \Delta R F F_{t}+\beta_{2} \Delta_{2} L E I_{t}+\beta_{3} C P T R_{t}+\beta_{4} \Delta_{4} D E L_{t}+\beta_{5} \Delta_{2} \text { MFore }_{t-1}+\beta_{6} E P U_{t}
$$

where, except for the constant and $\beta_{2}$, the other $\beta$ 's are expected to be positive. Estimating the model from 1991 Q2 to 2014 Q3 with an AR(1) correction yields:

$$
\begin{aligned}
D I_{t}=- & 0.040+0.035 \Delta R F F_{t}-0.793 \Delta_{2} L E I_{t}^{* *}+0.138 C P T R_{t}^{* *} \\
& (0.57)(1.42) \\
+ & 0.099 \Delta_{4} D E L_{t}^{* *}+0.218 \Delta_{2} \text { MFore }_{t-1}^{*}+0.655 E P U_{t}^{*}
\end{aligned}
$$

where absolute t-statistics are in parentheses, $R^{2}=0.901, \operatorname{AR}(1)=0.83^{* *}(11.49)$, equation standard error $=0.078, \operatorname{LM}(2)=2.51$ and $\mathrm{Q}(24)=21.55$. The coefficients have the expected signs and all but the change in the real federal funds rate are significant. ${ }^{7}$

The positive coefficient on contemporaneous EPU is consistent with economic policy uncertainty inducing tighter credit standards, which after a short lag slows loan growth consistent with both our finding of a significant impact of 4 lags of EPU on bank loan growth and Bassett, et al.'s (2014) result that loan growth slightly lags credit standards. We calculate by how much elevated levels of EPU resulted in tighter-than-otherwise changes in credit standards by multiplying the estimated coefficient on EPU in equation (6) by the actual levels of EPU minus the average of the series between 1991 Q1 and 2007 Q2, just before the start of the financial crisis in August 2007. As shown in Figure 7, although economic policy uncertainty had little visible effect on credit standards during the Great Recession, its elevated levels during the recovery are estimated to have resulted in less credit standard easing (negative readings in the index) as reflected by the adjusted line being below the actual.

When coupled with Basset, et al.'s (2014) finding that a one standard deviation shock to the credit standard variable lowers GDP by about a maximum of 0.8 percentage points after 10 quarters, our findings suggest that elevated levels of economic policy uncertainty, via the bank

\footnotetext{
${ }^{7}$ The insignificance of $\triangle R F F_{t}$ may reflect a short sample and lack of variation from the zero lower bound on the nominal funds rate. In longer samples, Aron et al. (2012) find that $\Delta R F F_{t}$ is highly significant in a similar model.
} 
lending channel, restrained GDP growth in the sluggish recovery from the Great Recession. To provide a rough gauge of the magnitude, note that from just before the financial crisis's onset, 2007 Q2 to 2010, the EPU index rose 80 points, translating into an estimated .0524 higher average level of the credit standard index. Scaled by the standard error in the model of equation 6 , the rise in EPU between 2007 and 2010 translates into about a 2/3 of a standard deviation shock to credit standards. In the model of Bassett et al. (2014), the peak effect of a shock of this magnitude would lower GDP by about 0.5 percentage points, implying that tighter-than-otherwise credit standards noticeably restrained economic growth - among other factors ${ }^{8}$ - during the sluggish recovery from the Great Recession. Coupled with the earlier VAR results, this suggests that about half of the impact of EPU on GDP occurs through the bank loan channel.

\section{Conclusion}

This study finds that economic policy uncertainty is strongly associated with slower real loan growth at both an aggregate level and across individual banks in the U.S., a qualitative finding that is robust to the inclusion of a set of significant economic and regulatory control variables and to using three different indexes from Baker, Bloom, and Davis (2015): their newspaper-based historical index, their shorter sample but more broadly defined index, and their index focused on finance-centric economic policy uncertainty. This implies that economic policy uncertainty affects the economy through a bank lending channel, and is consistent with the interpretation that the more elevated levels of economic policy uncertainty that tend to accompany recessions and recoveries restrained bank loan growth and, thus, economic activity.

Furthermore, the results have nuanced implications for financial reform and financial stability. These mainly arise from the finding that there is a smaller negative impact of economic policy uncertainty on loan growth at banks that are well capitalized, with less robust evidence that uncertainty effects are less negative at banks holding more cash. Most prominently, this evidence of loan supply side-effects at the level of individual banks suggests that moving to a more highly capitalized banking system could make economies more resilient to economic policy uncertaintythis is more so the case if countercyclical capital and liquidity buffer provisions prevent regulations

\footnotetext{
${ }^{8}$ For example, uncertainty effects on investment (Bloom, Bond, and Van Reenen, 2007) and hiring (Leduc and Liu, 2013), and as well as other effects on credit availability (Bassett et al., 2014) and wealth (e.g., Aron et al., 2012, and Mian and Sufi, 2011).
} 
from having pro-cyclical effects. ${ }^{9}$ Our results also imply that bank lending growth may have recently been aided in the U.S. by progress since early 2014 in allaying economic policy uncertainty following the transition to higher bank capital ratios induced by the Dodd-Frank Act. Because other studies have found important macro-economic effects of bank lending growth on the macroeconomy ${ }^{10}$ our findings are consistent with the view that high economic policy uncertainty may have slowed the U.S. economic recovery from the Great Recession by restraining overall credit growth through the bank lending channel.

\footnotetext{
${ }^{9}$ See Drehmann and Gambacorta (2012). Nevertheless, any gains in utility from improved short-run stability from tougher regulations could conceivably be offset by negative effects from increased regulation on long-run growth.

${ }^{10}$ See Bentolila, Jansen, Jiménez, and Ruano (2013), Bernanke, Lown, and Friedman (1991), and Kashyap and Stein (2000), inter alia.
} 


\section{References}

Aron, Janine, John V. Duca, John Muellbauer, Keiko Murata, and Anthony Murphy (2012). "Credit, Housing Collateral, and Consumption: Evidence from Japan, the UK, and the US". In: Review of Income and Wealth 58.3, pp. 397-423.

Ashcraft, Adam B. (2006). "New Evidence on the Lending Channel". In: Journal of Money, Credit and Banking, pp. 751-775.

Baker, Scott R., Nicholas Bloom, and Steven J. Davis (2015). Measuring Economic Policy Uncertainty. Tech. rep. National Bureau of Economic Research.

Bassett, William F., Mary Beth Chosak, John C. Driscoll, and Egon Zakrajšek (2014). "Changes in Bank Lending Standards and the Macroeconomy". In: Journal of Monetary Economics 62, pp. 23-40.

Bentolila, Samuel, Marcel Jansen, Gabriel Jiménez, and Sonia Ruano (2013). "When Credit Dries Up: Job Losses in the Great Recession". In:

Bernanke, Ben S., Cara S. Lown, and Benjamin M. Friedman (1991). "The Credit Crunch". In: Brookings Papers on Economic Activity 1991.2, pp. 205-247.

Bloom, Nicholas (2009). "The Impact of Uncertainty Shocks". In: Econometrica 77.3, pp. 623-685.

Bloom, Nicholas, Stephen Bond, and John Van Reenen (2007). "Uncertainty and Investment Dynamics". In: The Review of Economic Studies 74.2, pp. 391-415.

Bluedorn, John C., Christopher Bowdler, and Christoffer Koch (2014). "Heterogeneous Bank Lending Responses to Monetary Policy: New Evidence from a Real-Time Identification". In: Federal Reserve Bank of Dallas Working Paper.

Dewatripont, Mathias and Jean Tirole (1994). "A Theory of Debt and Equity: Diversity of Securities and Manager-Shareholder Congruence". In: The Quarterly Journal of Economics, pp. 10271054.

Drehmann, Mathias and Leonardo Gambacorta (2012). "The Effects of Countercyclical Capital Buffers on Bank Lending". In: Applied Economics Letters 19.7, pp. 603-608.

Duca, John V. and Tao Wu (2009). "Regulation and the Neo-Wicksellian Approach to Monetary Policy". In: Journal of Money, Credit and Banking 41.4, pp. 799-807.

Fernholz, Ricardo T. and Christoffer Koch (2016). "Why Are Big Banks Getting Bigger?" In: Federal Reserve Bank of Dallas Working Paper. 
Flannery, Mark J. (1989). "Capital Regulation and Insured Banks Choice of Individual Loan Default Risks". In: Journal of Monetary Economics 24.2, pp. 235-258.

Friedman, Benjamin M. and Kenneth N. Kuttner (1998). "Indicator Properties of the PaperBill Spread: Lessons from Recent Experience". In: Review of Economics and Statistics 80.1, pp. 3444 .

Gennotte, Gerard and David Pyle (1991). "Capital Controls and Bank Risk". In: Journal of Banking 8 Finance 15.4, pp. 805-824.

Gissler, Stefan, Jeremy Oldfather, and Doriana Ruffino (2016). "Lending on hold: Regulatory uncertainty and bank lending standards". In: Mimeo.

Jurado, Kyle, Sydney C Ludvigson, and Serena Ng (2015). "Measuring Uncertainty". In: American Economic Review 105.3, pp. 1177-1216.

Karnizova, Lilia and Jiaxiong Chris Li (2014). "Economic Policy Uncertainty, Financial Markets and Probability of US Recessions". In: Economics Letters 125.2, pp. 261-265.

Kashyap, Anil K. and Jeremy C. Stein (2000). "What Do a Million Observations on Banks Say About the Transmission of Monetary Policy?" In: American Economic Review, pp. 407-428.

Kishan, Ruby P. and Timothy P. Opiela (2000). "Bank Size, Bank Capital, and the Bank Lending Channel". In: Journal of Money, Credit and Banking, pp. 121-141.

Koch, Christoffer (2012). Regulatory Burden Rising. Tech. rep. Federal Reserve Bank of Dallas.

- (2015). "Deposit Interest Rate Ceilings as Credit Supply Shifters: Bank Level Evidence on the Effects of Regulation Q". In: Journal of Banking E Finance 61, pp. 316-326.

Leduc, Sylvain and Zheng Liu (2013). "Uncertainty and the Slow Labor Market Recovery". In: Federal Reserve Bank of San Francisco Economic Letter 21, p. 22.

Mian, Atif and Amir Sufi (2011). "House Prices, Home EquityBased Borrowing, and the US Household Leverage Crisis". In: The American Economic Review 101.5, pp. 2132-2156.

Stiglitz, Joseph E and Andrew Weiss (1981). "Credit Rationing in Markets with Imperfect Information". In: The American Economic Review 71.3, pp. 393-410.

Stokey, Nancy L. (2008). The Economics of Inaction: Stochastic Control Models with Fixed Costs. Princeton University Press.

Welsch, Roy and Edwin Kuh (1977). "Linear Regression Diagnostics". In: NBER Working Paper 173. 
Wu, Jing C. and Fan D. Xia (2014). "Measuring the Macroeconomic Impact of Monetary Policy at the Zero Lower Bound". In: Journal of Money, Credit, and Banking.

\section{Figures}

Figure 1: Total Real U.S. Bank Loans per Capita Indexed to Business Cycle Peak

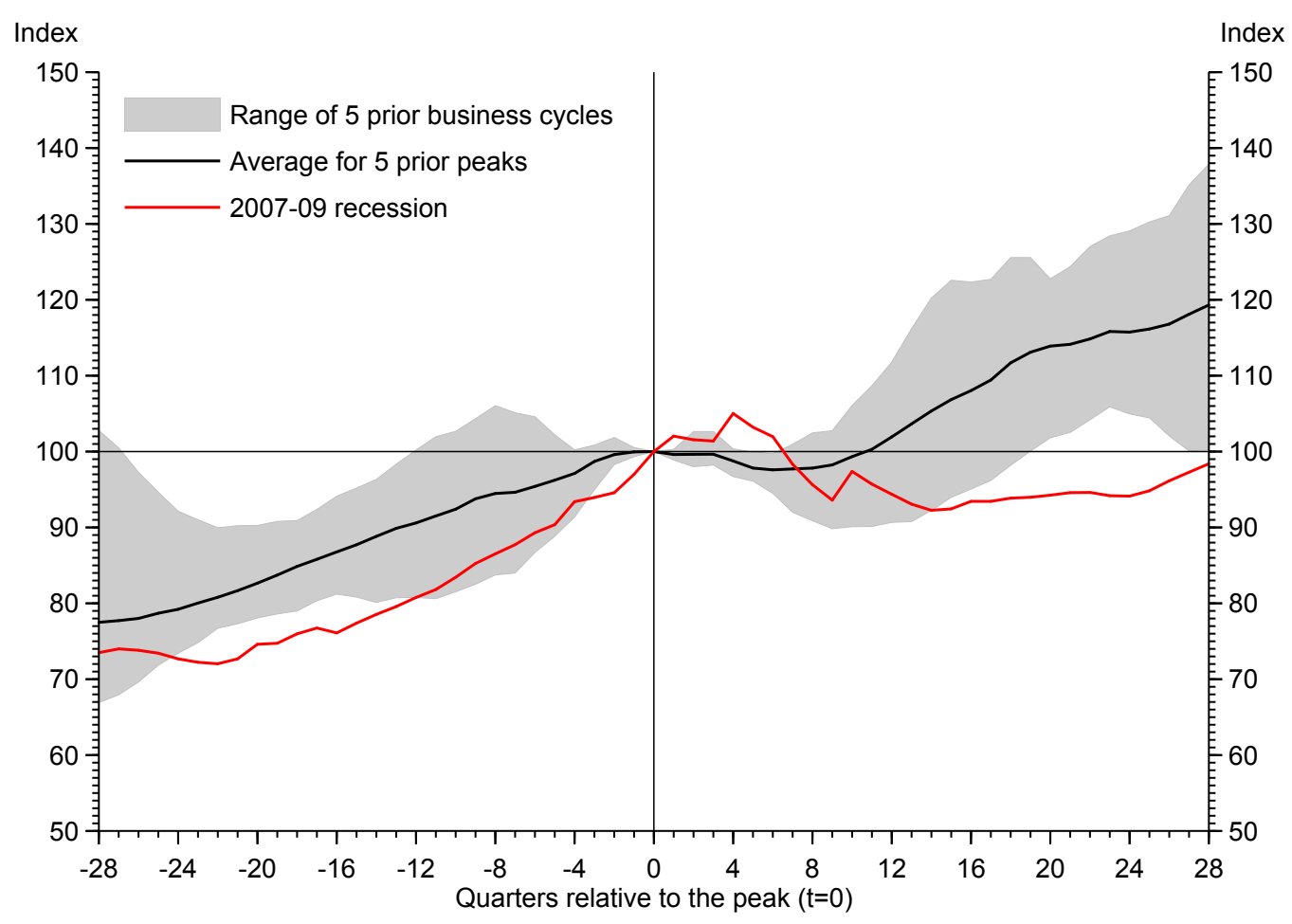


Figure 2: Regulatory Burdens on U.S. Commercial Banks Have Increased

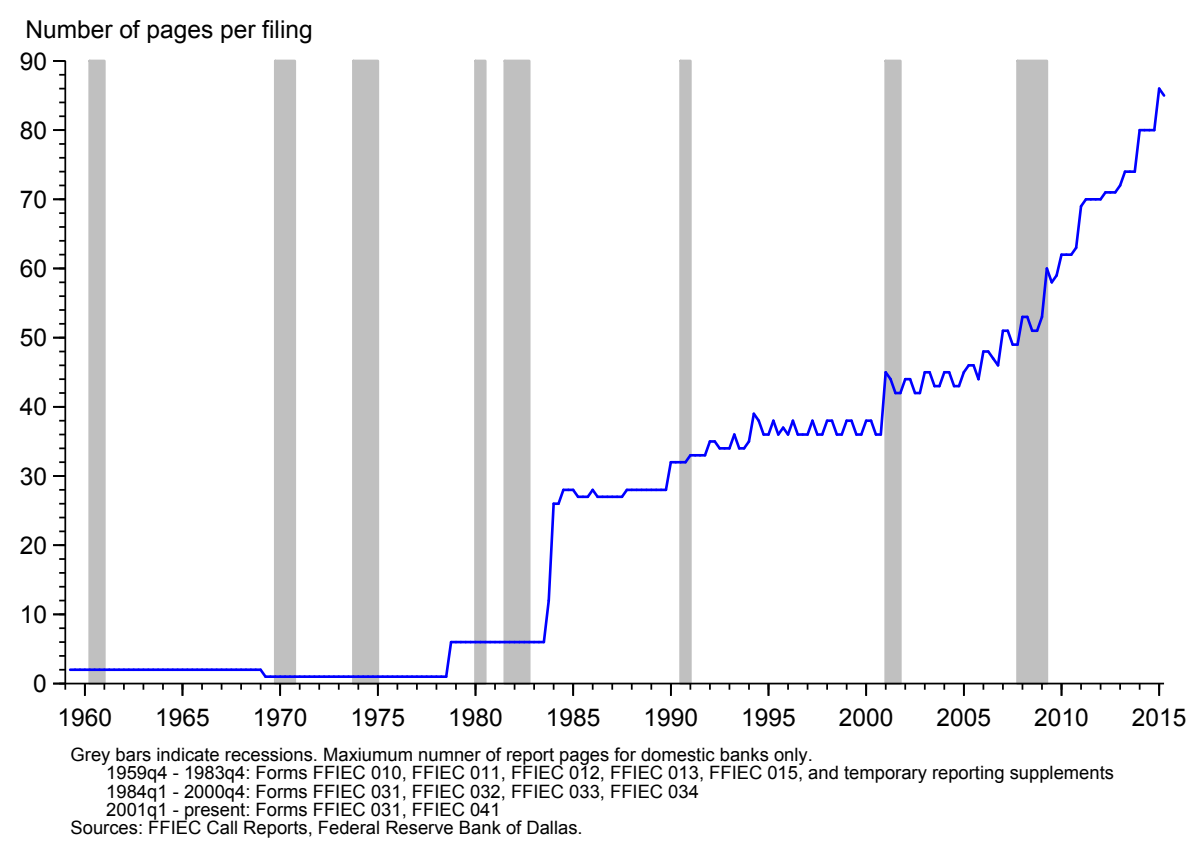

Figure 3: Economic Policy Uncertainty Tends to Shift Up Around Recessions and was Notably Higher in the Recovery from the Great Recession

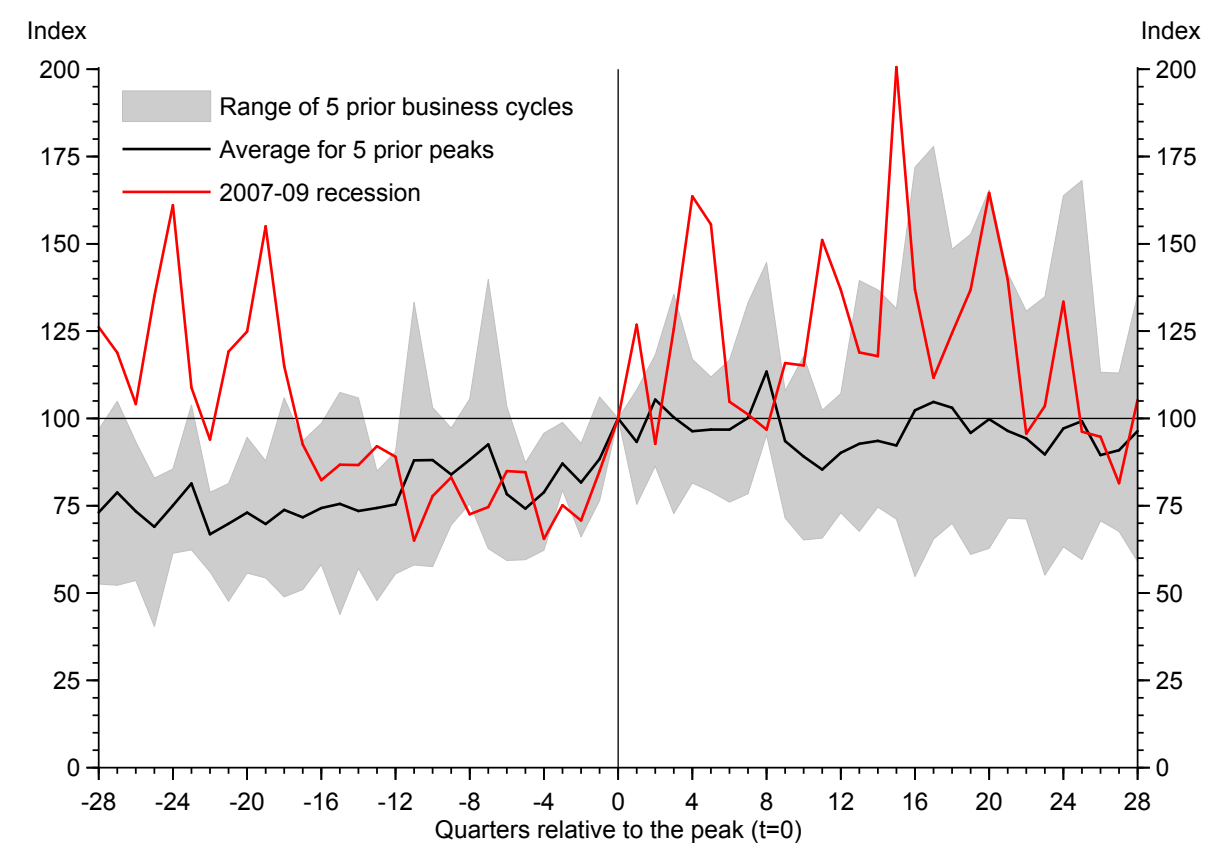


Figure 4: Economic Policy Uncertainty in an Elevated Range Since 1974, Especially During Recessions and Early in Economic Recoveries

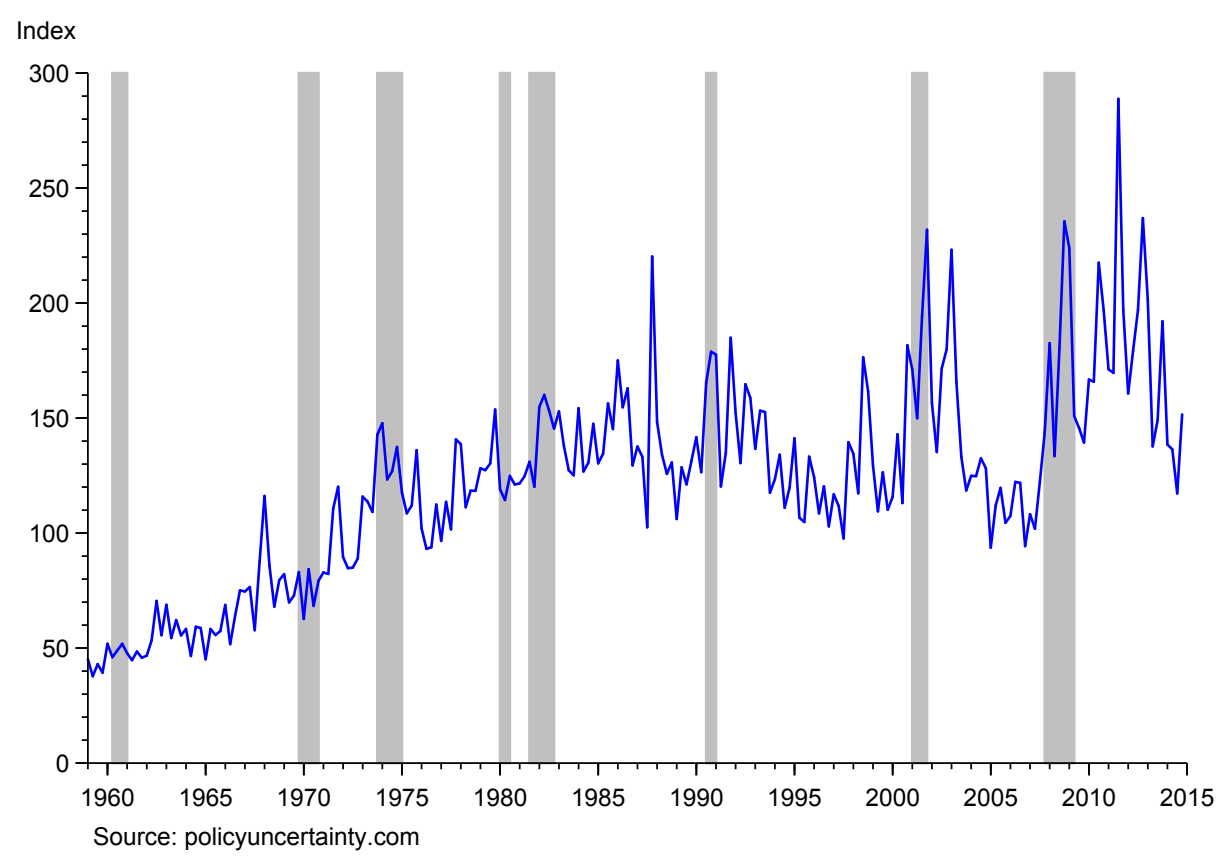

Figure 5: Economic Policy Uncertainty Rose More in Europe Following the Great Recession and Has Subsequently Receded Less than in the U.S.

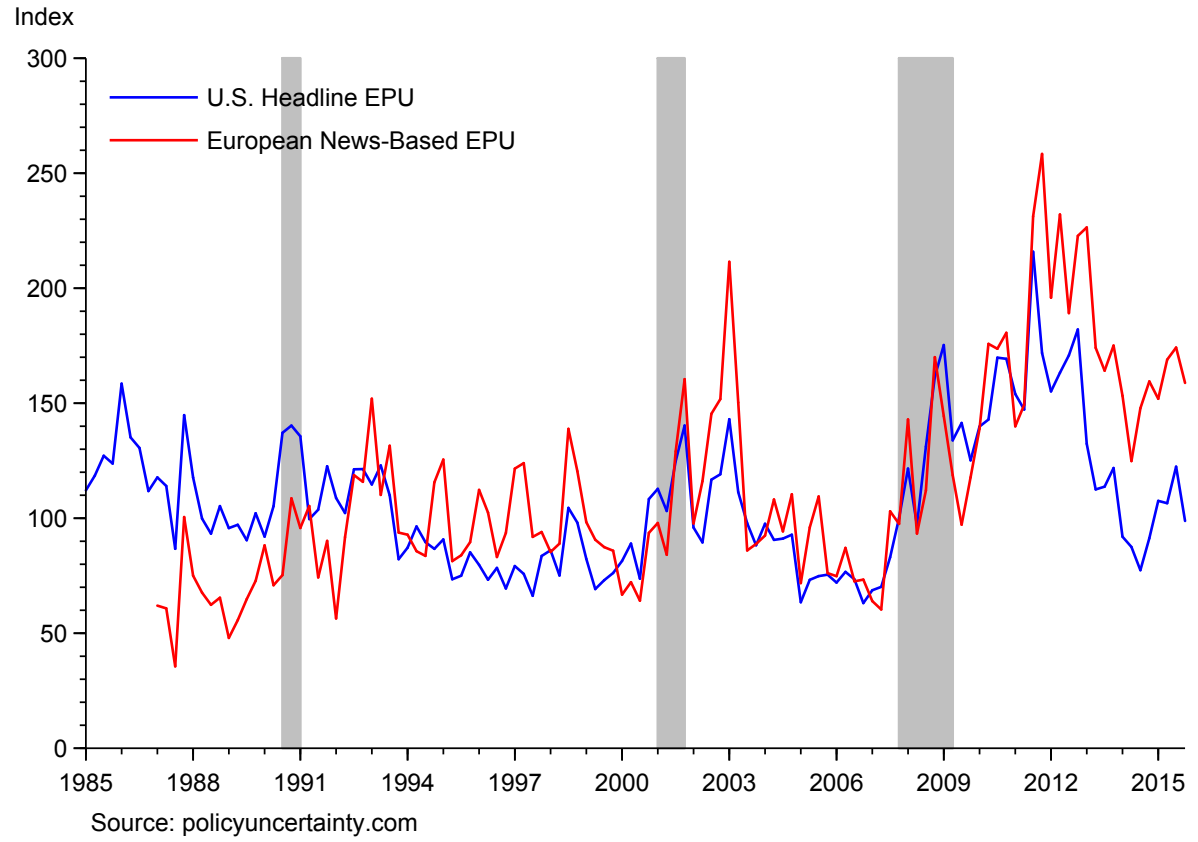


Figure 6: Impact of a One Standard Deviation Shock to EPU

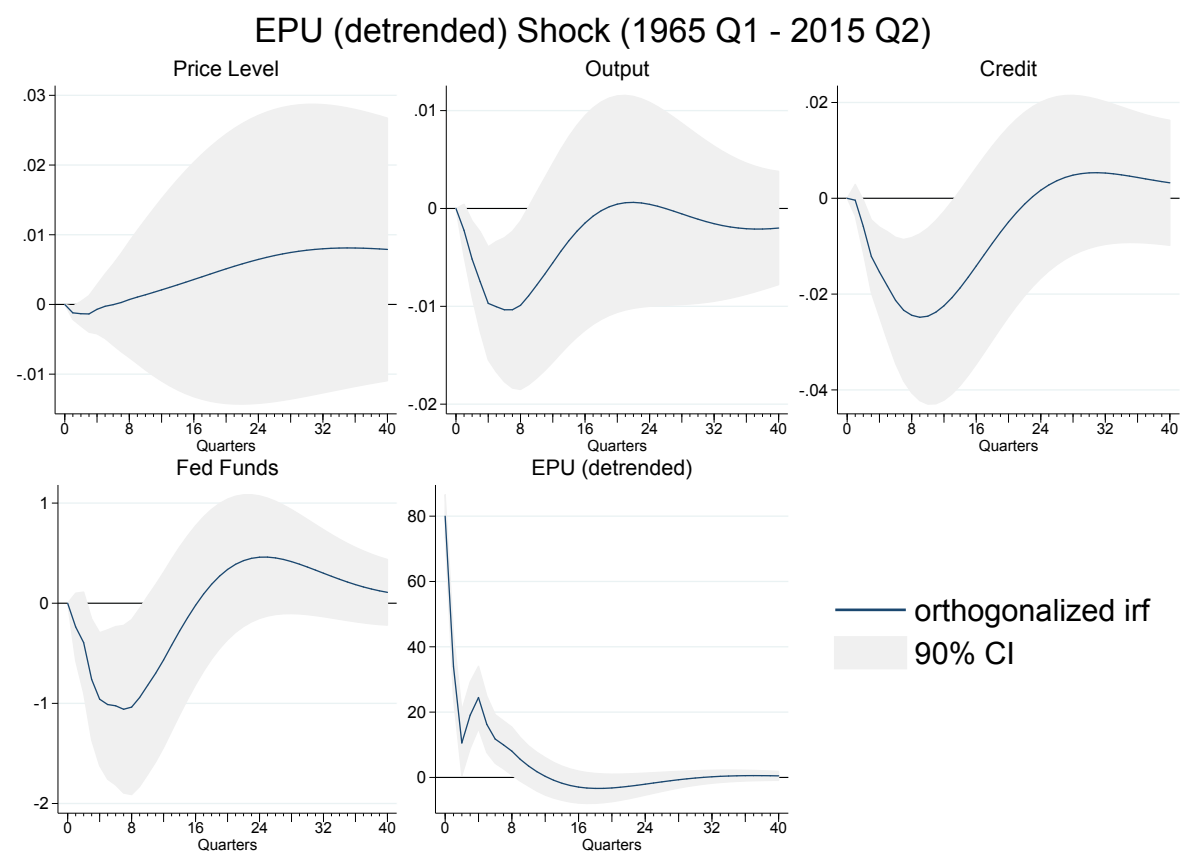

Figure 7: Changes in Bank Credit Standards and Economic Policy Uncertainy

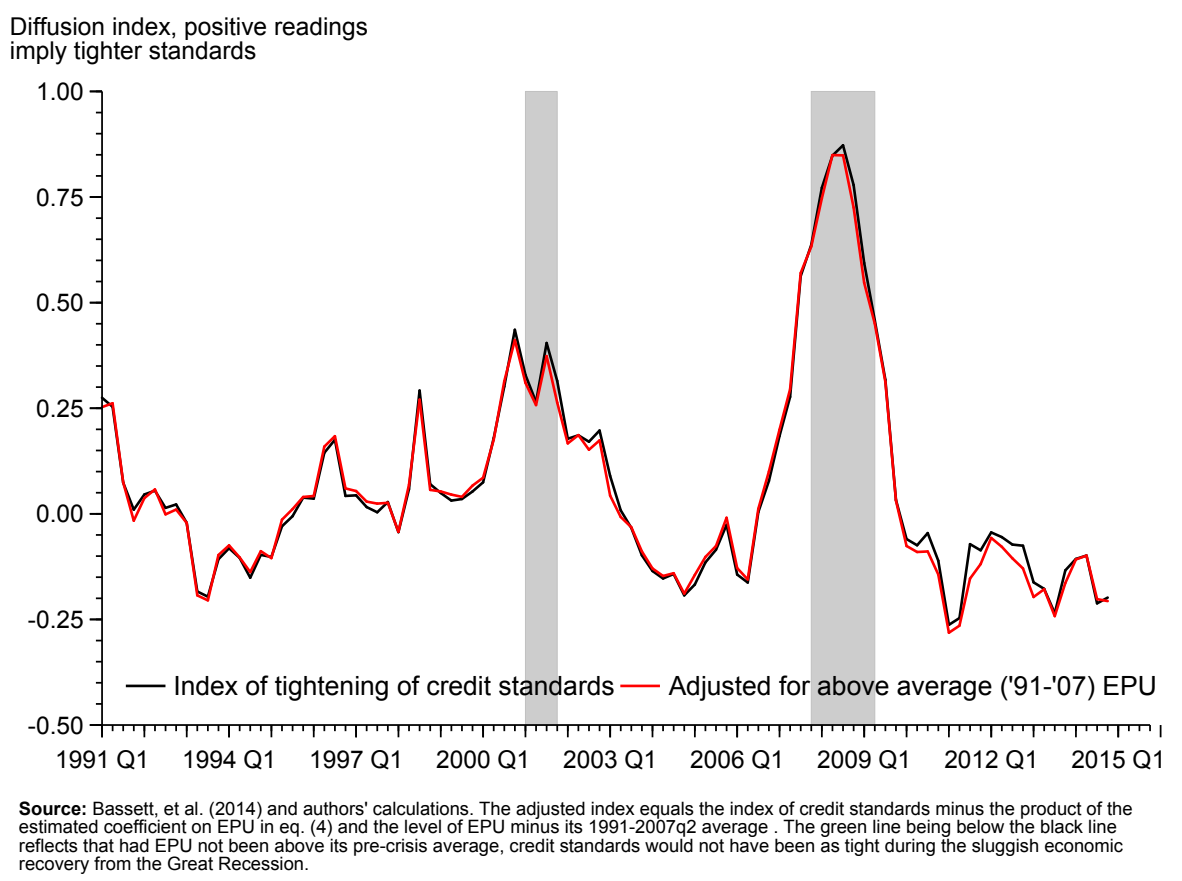




\section{Tables}

Table 1: Effects of Economic Policy Uncertainty on Real Overall Bank Loan Growth (quarterly, aggregate results)

\begin{tabular}{|c|c|c|c|c|}
\hline Controls & No Controls & $\begin{array}{l}\text { Non-regulatory } \\
\text { controls ( } \Delta \text { real } \\
\text { GDP, } \Delta \text { real fed } \\
\text { funds rate) }\end{array}$ & $\begin{array}{l}\text { Non-regulatory and } \\
\text { regulatory controls } \\
\text { without consumer } \\
\text { sentiment }\end{array}$ & $\begin{array}{l}\text { Non-regulatory and } \\
\text { regulatory controls } \\
\text { and consumer } \\
\text { sentiment } \\
\text { expectations }\end{array}$ \\
\hline $\begin{array}{l}\text { Total Loans } \\
\text { (sum of coefficients on } \\
\text { EPU lags, (standard } \\
\text { errors), (lags in quarters) }\end{array}$ & $\begin{array}{l}-3.79 * * * \\
(1.31) \\
(4 \text { lags })\end{array}$ & $\begin{array}{c}-2.23^{*} \\
(1.31) \\
(5 \text { lags })\end{array}$ & $\begin{array}{l}-2.27^{* *} \\
(1.08) \\
(2 \text { lags })\end{array}$ & $\begin{array}{c}-2.16^{*} \\
(1.20) \\
(2 \text { lags })\end{array}$ \\
\hline $\begin{array}{l}\text { C\&I Loans } \\
\text { (sum of coefficients on } \\
\text { EPU lags, (standard } \\
\text { errors), (lags in quarters) }\end{array}$ & $\begin{array}{l}-5.93^{* * *} \\
(1.70) \\
(4 \text { lags })\end{array}$ & $\begin{array}{l}-4.67^{* * *} \\
(1.55) \\
(3 \text { lags })\end{array}$ & $\begin{array}{l}-3.69^{* *} \\
(1.60) \\
(4 \text { lags })\end{array}$ & $\begin{array}{l}-6.35^{* * *} \\
(1.70) \\
(3 \text { lags })\end{array}$ \\
\hline $\begin{array}{l}\text { Real Estate Loans } \\
\text { (sum of coefficients on } \\
\text { EPU lags, (standard } \\
\text { errors), (lags in quarters) }\end{array}$ & $\begin{array}{l}-1.20 \\
(1.29) \\
(4 \text { lags })\end{array}$ & $\begin{array}{l}0.29 \\
(1.35) \\
(5 \text { lags })\end{array}$ & $\begin{array}{l}-0.43 \\
(1.15) \\
(2 \text { lags })\end{array}$ & $\begin{array}{l}0.41 \\
(1.29) \\
(2 \text { lags })\end{array}$ \\
\hline $\begin{array}{l}\text { Consumer Loans } \\
\text { (sum of coefficients on } \\
\text { EPU lags, (standard } \\
\text { errors), (lags in quarters) }\end{array}$ & $\begin{array}{l}-0.85 \\
(1.63) \\
(5 \text { lags })\end{array}$ & $\begin{array}{l}-0.09 \\
(1.57) \\
(4 \text { lags })\end{array}$ & $\begin{array}{l}-0.48 \\
(1.38) \\
(2 \text { lags })\end{array}$ & $\begin{array}{l}1.50 \\
(1.26) \\
(1 \mathrm{lag})\end{array}$ \\
\hline
\end{tabular}

Notes: Coefficients are multiplied by 100. Loans are adjusted for changes in reporting and deflated using the GDP deflator. Lags are selected based on the Akaike's information criterion. ***, **, * denote significance at the 99, 95, and 90 percent confidence levels. Controls include lagged loan growth, macroeconomic, and regulatory variables. Sample period is 1961 Q4 to 2014 Q3. 
Table 2: Effects of Historical Economic Policy Uncertainty on Real Disaggregated Total Bank Loan Growth 1961 Q4 - 2014 Q3

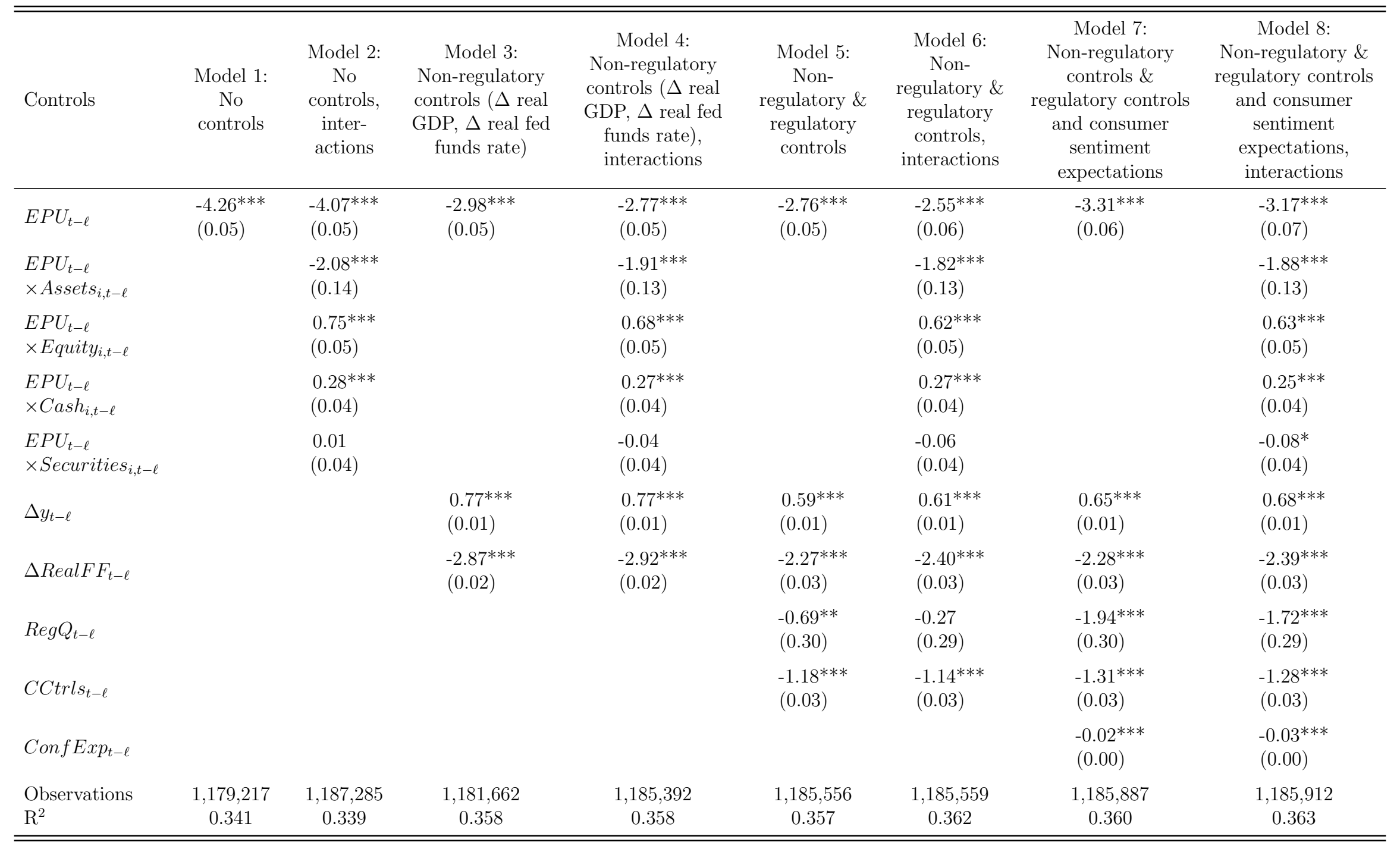

Notes: Lag length set to 4. Coefficients of EPU and bank-level characteristics interacted with EPU are multiplied by 100. All coefficients are the sum of all four lags. Bank loan growth is annualized quarter-over-quarter percentage growth rates. ${ }^{* * *}, * *, *$ denote significance at the 99,95 , and 90 percent level and standard errors are in parentheses. Differences in the numbers of observations across the models partly reflect the inclusion of time series controls and individual bank characteristics affect the number of unusual outliers screened out by the DFIT procedure used to limit the influence of outliers. 
Table 3: Effects of Historical Economic Policy Uncertainty on Real Disaggregated Categories of Bank Loan Growth 1961 Q4 - 2014 Q3

\begin{tabular}{|c|c|c|c|c|c|c|c|c|}
\hline Controls & $\begin{array}{c}\text { Model 1: } \\
\text { No } \\
\text { controls }\end{array}$ & $\begin{array}{l}\text { Model 2: } \\
\text { No } \\
\text { controls, } \\
\text { inter- } \\
\text { actions }\end{array}$ & $\begin{array}{c}\text { Model } 3: \\
\text { Non-regulatory } \\
\text { controls ( } \Delta \text { real } \\
\text { GDP, } \Delta \text { real fed } \\
\text { funds rate) }\end{array}$ & $\begin{array}{c}\text { Model } 4: \\
\text { Non-regulatory } \\
\text { controls ( } \Delta \text { real } \\
\text { GDP, } \Delta \text { real fed } \\
\text { funds rate), } \\
\text { interactions }\end{array}$ & $\begin{array}{l}\text { Model 5: } \\
\text { Non- } \\
\text { regulatory \& } \\
\text { regulatory } \\
\text { controls }\end{array}$ & $\begin{array}{l}\text { Model 6: } \\
\text { Non- } \\
\text { regulatory \& } \\
\text { regulatory } \\
\text { controls, } \\
\text { interactions }\end{array}$ & $\begin{array}{c}\text { Model 7: } \\
\text { Non-regulatory } \\
\text { controls \& } \\
\text { regulatory controls } \\
\text { and consumer } \\
\text { sentiment } \\
\text { expectations }\end{array}$ & $\begin{array}{c}\text { Model 8: } \\
\text { Non-regulatory \& } \\
\text { regulatory controls } \\
\text { and consumer } \\
\text { sentiment } \\
\text { expectations, } \\
\text { interactions }\end{array}$ \\
\hline \multicolumn{9}{|l|}{ C\&I Loans } \\
\hline$E P U_{t-\ell}$ & $\begin{array}{l}-9.68^{* * *} \\
(0.16)\end{array}$ & $\begin{array}{l}-9.29^{* * *} \\
(0.18)\end{array}$ & $\begin{array}{l}-8.37^{* * *} \\
(0.17)\end{array}$ & $\begin{array}{l}-7.69^{* * *} \\
(0.19)\end{array}$ & $\begin{array}{l}-8.51^{* * *} \\
(0.18)\end{array}$ & $\begin{array}{l}-7.89^{* * *} \\
(0.19)\end{array}$ & $\begin{array}{l}-9.25^{* * *} \\
(0.23)\end{array}$ & $\begin{array}{l}-8.78^{* * * *} \\
(0.24)\end{array}$ \\
\hline $\begin{array}{l}E P U_{t-\ell} \\
\times \text { Assets }_{i, t-\ell}\end{array}$ & & $\begin{array}{l}-1.66^{* * *} \\
(0.43)\end{array}$ & & $\begin{array}{l}-1.76^{* * *} \\
(0.42)\end{array}$ & & $\begin{array}{l}-1.68^{* * *} \\
(0.42)\end{array}$ & & $\begin{array}{l}-1.62^{* * *} \\
(0.42)\end{array}$ \\
\hline $\begin{array}{l}E P U_{t-\ell} \\
\times \text { Equity }_{i, t-\ell}\end{array}$ & & $\begin{array}{l}1.82^{* * *} \\
(0.17)\end{array}$ & & $\begin{array}{l}1.81^{* * *} \\
(0.16)\end{array}$ & & $\begin{array}{l}1.79^{* * *} \\
(0.16)\end{array}$ & & $\begin{array}{l}1.83^{* * *} \\
(0.16)\end{array}$ \\
\hline $\begin{array}{l}E P U_{t-\ell} \\
\times \operatorname{Cash}_{i, t-\ell}\end{array}$ & & $\begin{array}{l}0.92^{* * *} \\
(0.14)\end{array}$ & & $\begin{array}{l}0.88^{* * *} \\
(0.14)\end{array}$ & & $\begin{array}{l}0.82^{* * *} \\
(0.14)\end{array}$ & & $\begin{array}{l}0.76^{* * *} \\
(0.14)\end{array}$ \\
\hline $\begin{array}{l}E P U_{t-\ell} \\
\times \text { Securities } s_{i, t-\ell}\end{array}$ & & $\begin{array}{l}0.09 \\
(0.14)\end{array}$ & & $\begin{array}{l}0.04 \\
(0.13)\end{array}$ & & $\begin{array}{l}0.01 \\
(0.13)\end{array}$ & & $\begin{array}{l}-0.01 \\
(0.13)\end{array}$ \\
\hline $\begin{array}{l}\text { Observations } \\
\mathrm{R}^{2}\end{array}$ & $\begin{array}{c}849,292 \\
0.182\end{array}$ & $\begin{array}{c}860,066 \\
0.169\end{array}$ & $\begin{array}{c}854,158 \\
0.183\end{array}$ & $\begin{array}{c}858,354 \\
0.175\end{array}$ & $\begin{array}{c}858,435 \\
0.180\end{array}$ & $\begin{array}{c}858,140 \\
0.177\end{array}$ & $\begin{array}{c}857,538 \\
0.182\end{array}$ & $\begin{array}{c}857,940 \\
0.178\end{array}$ \\
\hline \multicolumn{9}{|l|}{ Real Estate } \\
\hline$E P U_{t-\ell}$ & $\begin{array}{l}-3.76^{* * *} \\
(0.06)\end{array}$ & $\begin{array}{l}-3.56^{* * *} \\
(0.07)\end{array}$ & $\begin{array}{l}-2.20^{* * * *} \\
(0.07)\end{array}$ & $\begin{array}{l}-1.92^{* * *} \\
(0.07)\end{array}$ & $\begin{array}{l}-2.02^{* * *} \\
(0.07)\end{array}$ & $\begin{array}{l}-1.80^{* * *} \\
(0.07)\end{array}$ & $\begin{array}{l}-2.05^{* * *} \\
(0.08)\end{array}$ & $\begin{array}{l}-1.95^{* * *} \\
(0.08)\end{array}$ \\
\hline $\begin{array}{l}E P U_{t-\ell} \\
\times \text { Assets }_{i, t-\ell}\end{array}$ & & $\begin{array}{l}-1.76^{* * * *} \\
(0.18)\end{array}$ & & $\begin{array}{l}-1.49^{* * * *} \\
(0.17)\end{array}$ & & $\begin{array}{l}-1.33^{* * *} \\
(0.17)\end{array}$ & & $\begin{array}{l}-1.33^{* * *} \\
(0.17)\end{array}$ \\
\hline $\begin{array}{l}E P U_{t-\ell} \\
\times E q u i t y_{i, t-\ell}\end{array}$ & & $\begin{array}{l}1.21^{* * *} \\
(0.07)\end{array}$ & & $\begin{array}{l}1.10^{* * *} \\
(0.06)\end{array}$ & & $\begin{array}{l}1.03 * * * \\
(0.06)\end{array}$ & & $\begin{array}{l}1.04^{* * *} \\
(0.06)\end{array}$ \\
\hline $\begin{array}{l}E P U_{t-\ell} \\
\times \operatorname{Cash}_{i, t-\ell}\end{array}$ & & $\begin{array}{l}0.44^{* * *} \\
(0.06)\end{array}$ & & $\begin{array}{l}0.42^{* * *} \\
(0.05)\end{array}$ & & $\begin{array}{l}0.41^{* * *} \\
(0.05)\end{array}$ & & $\begin{array}{l}0.40^{* * *} \\
(0.05)\end{array}$ \\
\hline $\begin{array}{l}E P U_{t-\ell} \\
\times \text { Securities }_{i, t-\ell}\end{array}$ & & $\begin{array}{l}0.11^{*} \\
(0.05)\end{array}$ & & $\begin{array}{l}0.10^{*} \\
(0.05)\end{array}$ & & $\begin{array}{l}0.08 \\
(0.05)\end{array}$ & & $\begin{array}{l}0.07 \\
(0.05)\end{array}$ \\
\hline Observations & $1,169,135$ & $1,179,910$ & $1,174,009$ & $1,178,763$ & $1,178,761$ & $1,179,456$ & $1,178,890$ & $1,179,522$ \\
\hline $\mathrm{R}^{2}$ & 0.262 & 0.251 & 0.270 & 0.266 & 0.268 & 0.268 & 0.270 & 0.270 \\
\hline
\end{tabular}

Notes: Lag length set to 4 . Coefficients are multiplied by 100 and the sume of all four lags. Bank loan growth is annualized quarter-over-quarter percentage growth rates. ***, $* *, *$ denote significance at the 99,95 , and 90 percent level and standard errors are in parentheses. Differences in the numbers of observations across the models partly reflect the inclusion of time series controls and individual bank characteristics affect the number of unusual outliers screened out by the DFIT procedure used to limit the influence of outliers. 
Table 3: Effects of Historical Economic Policy Uncertainty on Real Disaggregated Categories of Bank Loan Growth 1961 Q4 - 2014 Q3 (continued)

\begin{tabular}{|c|c|c|c|c|c|c|c|c|}
\hline Controls & $\begin{array}{c}\text { Model 1: } \\
\text { No } \\
\text { controls }\end{array}$ & $\begin{array}{l}\text { Model 2: } \\
\text { No } \\
\text { controls, } \\
\text { inter- } \\
\text { actions }\end{array}$ & $\begin{array}{c}\text { Model } 3: \\
\text { Non-regulatory } \\
\text { controls ( } \Delta \text { real } \\
\text { GDP, } \Delta \text { real fed } \\
\text { funds rate) }\end{array}$ & $\begin{array}{c}\text { Model 4: } \\
\text { Non-regulatory } \\
\text { controls ( } \Delta \text { real } \\
\text { GDP, } \Delta \text { real fed } \\
\text { funds rate), } \\
\text { interactions }\end{array}$ & $\begin{array}{l}\text { Model 5: } \\
\text { Non- } \\
\text { regulatory \& } \\
\text { regulatory } \\
\text { controls }\end{array}$ & $\begin{array}{l}\text { Model 6: } \\
\text { Non- } \\
\text { regulatory \& } \\
\text { regulatory } \\
\text { controls, } \\
\text { interactions }\end{array}$ & $\begin{array}{c}\text { Model 7: } \\
\text { Non-regulatory } \\
\text { controls \& } \\
\text { regulatory controls } \\
\text { and consumer } \\
\text { sentiment } \\
\text { expectations }\end{array}$ & $\begin{array}{l}\text { Model 8: } \\
\text { Non-regulatory \& } \\
\text { regulatory controls } \\
\text { and consumer } \\
\text { sentiment } \\
\text { expectations, } \\
\text { interactions }\end{array}$ \\
\hline \multicolumn{9}{|l|}{ Consumer } \\
\hline$E P U_{t-\ell}$ & $\begin{array}{l}-5.44^{* * *} \\
(0.08)\end{array}$ & $\begin{array}{l}-5.53^{* * *} \\
(0.09)\end{array}$ & $\begin{array}{l}-3.90^{* * * *} \\
(0.09)\end{array}$ & $\begin{array}{l}-3.78^{* * *} \\
(0.09)\end{array}$ & $\begin{array}{l}-3.84^{* * *} \\
(0.09)\end{array}$ & $\begin{array}{l}-3.76^{* * *} \\
(0.09)\end{array}$ & $\begin{array}{l}-5.04^{* * *} \\
(0.11)\end{array}$ & $\begin{array}{l}-4.97^{* * * *} \\
(0.11)\end{array}$ \\
\hline $\begin{array}{l}E P U_{t-1} \\
\times \text { Assets }_{i, t-\ell}\end{array}$ & & $\begin{array}{l}-2.06^{* * *} \\
(0.23)\end{array}$ & & $\begin{array}{l}-1.77^{* * *} \\
(0.22)\end{array}$ & & $\begin{array}{l}-1.59^{* * *} \\
(0.22)\end{array}$ & & $\begin{array}{l}-1.69^{* * *} \\
(0.22)\end{array}$ \\
\hline $\begin{array}{l}E P U_{t-1} \\
\times \text { Equity }_{i, t-\ell}\end{array}$ & & $\begin{array}{l}0.83^{* * *} \\
(0.08)\end{array}$ & & $\begin{array}{l}0.73^{* * *} \\
(0.08)\end{array}$ & & $\begin{array}{l}0.66^{* * *} \\
(0.08)\end{array}$ & & $\begin{array}{l}0.71^{* * *} \\
(0.08)\end{array}$ \\
\hline $\begin{array}{l}E P U_{t-1} \\
\times \operatorname{Cash}_{i, t-\ell}\end{array}$ & & $\begin{array}{l}0.60 * * * \\
(0.07)\end{array}$ & & $\begin{array}{l}0.62^{* * *} \\
(0.07)\end{array}$ & & $\begin{array}{l}0.57^{* * *} \\
(0.07)\end{array}$ & & $\begin{array}{l}0.56^{* * *} \\
(0.07)\end{array}$ \\
\hline $\begin{array}{l}E P U_{t-1} \\
\times \text { Securities }_{i, t-\ell}\end{array}$ & & $\begin{array}{l}0.05 \\
(0.07)\end{array}$ & & $\begin{array}{l}0.00 \\
(0.07)\end{array}$ & & $\begin{array}{l}-0.02 \\
(0.07)\end{array}$ & & $\begin{array}{l}-0.04 \\
(0.07)\end{array}$ \\
\hline Observations & $1,102,474$ & $1,113,952$ & $1,106,396$ & $1,112,226$ & $1,111,083$ & $1,112,754$ & $1,111,081$ & $1,112,601$ \\
\hline $\mathrm{R}^{2}$ & 0.286 & 0.271 & 0.292 & 0.283 & 0.287 & 0.284 & 0.290 & 0.288 \\
\hline
\end{tabular}

Notes: Lag length set to 4 . Coefficients are multiplied by 100 and the sum of all four lags. Bank loan growth is annualized quarter-over-quarter percentage growth rates. ***, $* *, *$ denote significance at the 99,95 , and 90 percent level and standard errors are in parentheses. Differences in the numbers of observations across the models partly reflect the inclusion of time series controls and individual bank characteristics affect the number of unusual outliers screened out by the DFIT procedure used to limit the influence of outliers. 
Table 4: Estimated Effects of High Levels of Economic Policy Uncertainty on Real Bank Loan Growth Since the Onset of the Great Recession

\begin{tabular}{|c|c|c|c|}
\hline Time Period & $\begin{array}{c}\text { Average extent that } E P U \\
\text { exceeded its } 2007 \mathrm{Q} 2 \text { level } \\
\text { over specified time period } \\
\text { (index points) }\end{array}$ & $\begin{array}{c}\text { Estimated effect EPU on bank } \\
\text { loan growth (SAAR) median } \\
\text { bank response (model } 8) \\
\text { (percentage points)* }\end{array}$ & $\begin{array}{c}\text { Estimated effect EPU on } \\
\text { bank loan growth (SAAR) } \\
\text { using } 50 \% \text { weight on largest } \\
\text { banks, } 50 \% \text { on median bank } \\
\text { (percentage points)** }\end{array}$ \\
\hline 2007 Q4 - 2011 Q4 & 81.0 & -2.6 & -2.9 \\
\hline 2007 Q4 - 2012 Q4 & 83.1 & -2.6 & -3.0 \\
\hline 2007 Q4 - 2013 Q4 & 80.7 & -2.6 & -2.9 \\
\hline
\end{tabular}

* Equals column 1 multiplied by -.0317 (non-interacted EPU coefficient/100 from model 8 in Table 2).

** Equals column 1 multiplied by -.0364 (one-half of non-interacted EPU coefficient/100, plus one-fourth times the coefficient/100 on EPU interacted with assets from model 8 in Table 2). 
Table 5: Effects of Post-1984 Economic Policy Uncertainty on Real Aggregate Bank Loan Growth 1986 Q2 - 2014 Q3

\begin{tabular}{|c|c|c|c|c|c|c|}
\hline Controls & Model 1: No controls & $\begin{array}{c}\text { Model } 2: \\
\text { Non-regulatory } \\
\text { controls ( } \Delta \text { real GDP, } \\
\Delta \text { real fed funds rate) }\end{array}$ & $\begin{array}{l}\text { Model 3: Non-regulatory } \\
\text { controls \& regulatory } \\
\text { controls and consumer } \\
\text { sentiment expectations }\end{array}$ & Model 4: No controls & $\begin{array}{c}\text { Model } 5: \\
\text { Non-regulatory } \\
\text { controls ( } \Delta \text { real GDP, } \\
\Delta \text { real fed funds rate) }\end{array}$ & $\begin{array}{l}\text { Model 6: Non-regulatory } \\
\text { controls \& regulatory } \\
\text { controls and consumer } \\
\text { sentiment expectations }\end{array}$ \\
\hline EPU Variable: & EPU1985 & EPU1985 & EPU1985 & EPUFin & EPUFin & EPUFin \\
\hline \multicolumn{7}{|l|}{ Loan Type: } \\
\hline Total Loans & $\begin{array}{l}-4.69^{* * *} \\
(1.49) \\
3 \text { lags }\end{array}$ & $\begin{array}{l}-3.19^{* * *} \\
(1.44) \\
3 \text { lags }\end{array}$ & $\begin{array}{l}-2.76^{*} \\
(1.60) \\
3 \text { lags }\end{array}$ & $\begin{array}{l}-2.99^{* * *} \\
(0.51) \\
4 \text { lags }\end{array}$ & $\begin{array}{l}-1.54^{* * *} \\
(0.59) \\
3 \text { lags }\end{array}$ & $\begin{array}{l}-1.33^{* *} \\
(0.63) \\
3 \text { lags }\end{array}$ \\
\hline C\&I Loans & $\begin{array}{l}-3.08^{*} \\
(1.72) \\
4 \text { lags }\end{array}$ & $\begin{array}{c}-1.07 \\
(1.51) \\
1 \mathrm{lag}\end{array}$ & $\begin{array}{l}-1.38 \\
(1.75) \\
1 \mathrm{lag}\end{array}$ & $\begin{array}{l}-2.58^{* * *} \\
(0.59) \\
4 \text { lags }\end{array}$ & $\begin{array}{c}-0.44 \\
(0.42) \\
1 \mathrm{lag}\end{array}$ & $\begin{array}{c}-0.48 \\
(0.44) \\
1 \mathrm{lag}\end{array}$ \\
\hline Real Estate & $\begin{array}{l}-2.78 \\
(1.71) \\
2 \text { lags }\end{array}$ & $\begin{array}{c}-1.73 \\
(1.83) \\
2 \text { lags }\end{array}$ & $\begin{array}{l}0.36 \\
(1.98) \\
2 \text { lags }\end{array}$ & $\begin{array}{l}-1.91^{* * *} \\
(0.56) \\
4 \text { lags }\end{array}$ & $\begin{array}{l}-2.19^{* * *} \\
(0.81) \\
4 \text { lags }\end{array}$ & $\begin{array}{c}-0.49 \\
(0.77) \\
3 \text { lags }\end{array}$ \\
\hline Consumer & $\begin{array}{l}-1.77 \\
(1.66) \\
2 \text { lags }\end{array}$ & $\begin{array}{l}-0.96 \\
(1.83) \\
2 \text { lags }\end{array}$ & $\begin{array}{l}-0.96 \\
(2.14) \\
2 \text { lags }\end{array}$ & $\begin{array}{l}-0.81^{* * *} \\
(0.59) \\
4 \text { lags }\end{array}$ & $\begin{array}{r}-0.130 \\
(0.70) \\
2 \text { lags }\end{array}$ & $\begin{array}{c}-0.053 \\
(0.76) \\
2 \text { lags }\end{array}$ \\
\hline
\end{tabular}

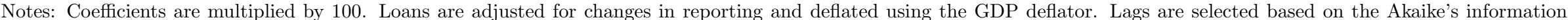

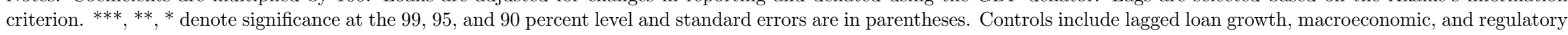
variables. Sample period is 1961 Q4 to 2014 Q3. 
Table 6: Effects of Post-1984 Aggregate Economic Policy Uncertainty (EPU1985) on Real Disaggregated Categories of Bank Level Loan Growth 1986 Q2 - 2014 Q3

\begin{tabular}{|c|c|c|c|c|c|c|}
\hline Controls & Model 1: No controls & $\begin{array}{l}\text { Model 2: No controls, } \\
\text { inter-actions }\end{array}$ & $\begin{array}{l}\text { Model 3: Non-regulatory } \\
\text { controls ( } \Delta \text { real GDP, } \Delta \\
\text { real fed funds rate) }\end{array}$ & $\begin{array}{c}\text { Model 4: } \\
\text { Non-regulatory } \\
\text { controls }(\Delta \text { real GDP, } \\
\Delta \text { real fed funds } \\
\text { rate), interactions }\end{array}$ & $\begin{array}{c}\text { Model 5: } \\
\text { Non-regulatory } \\
\text { controls \& regulatory } \\
\text { controls and } \\
\text { consumer sentiment } \\
\text { expectations }\end{array}$ & $\begin{array}{c}\text { Model 6: Non-regulatory } \\
\& \text { regulatory controls } \\
\text { and consumer sentiment } \\
\text { expectations, } \\
\text { interactions }\end{array}$ \\
\hline \multicolumn{7}{|l|}{ Total Loans } \\
\hline$\overline{E P U_{t-\ell}}$ & $\begin{array}{l}-3.76^{* * *} \\
(0.06)\end{array}$ & $\begin{array}{l}-3.71^{* * *} \\
(0.07)\end{array}$ & $\begin{array}{l}-3.26^{* * *} \\
(0.07)\end{array}$ & $\begin{array}{l}-3.13^{* * *} \\
(0.07)\end{array}$ & $\begin{array}{l}-3.13^{* * *} \\
(0.08)\end{array}$ & $\begin{array}{l}-3.00^{* * *} \\
(0.08)\end{array}$ \\
\hline $\begin{array}{l}E P U_{t-\ell} \\
\times \text { Assets }_{i, t-\ell}\end{array}$ & & $\begin{array}{l}-2.37^{* * *} \\
(0.23)\end{array}$ & & $\begin{array}{l}-2.33^{* * *} \\
(0.23)\end{array}$ & & $\begin{array}{l}-2.27^{* * *} \\
(0.23)\end{array}$ \\
\hline $\begin{array}{l}E P U_{t-\ell} \\
\times \text { Equity }_{i, t-\ell}\end{array}$ & & $\begin{array}{l}0.93^{* * *} \\
(0.09)\end{array}$ & & $\begin{array}{l}0.91^{* * *} \\
(0.08)\end{array}$ & & $\begin{array}{l}0.91^{* * *} \\
(0.08)\end{array}$ \\
\hline $\begin{array}{l}E P U_{t-\ell} \\
\times \operatorname{Cash}_{i, t-\ell}\end{array}$ & & $\begin{array}{l}0.05 \\
(0.08)\end{array}$ & & $\begin{array}{l}0.07 \\
(0.08)\end{array}$ & & $\begin{array}{l}0.07 \\
(0.08)\end{array}$ \\
\hline $\begin{array}{l}E P U_{t-\ell} \\
\times \text { Securities }_{i, t-\ell}\end{array}$ & & $\begin{array}{l}0.25^{* * *} \\
(0.07)\end{array}$ & & $\begin{array}{l}0.18^{* * *} \\
(0.07)\end{array}$ & & $\begin{array}{l}0.18^{* * *} \\
(0.07)\end{array}$ \\
\hline $\begin{array}{l}\text { Observations } \\
\mathrm{R}^{2}, \text { corrected }\end{array}$ & $\begin{array}{c}523,835 \\
0.417\end{array}$ & $\begin{array}{c}526,839 \\
0.423\end{array}$ & $\begin{array}{c}525,922 \\
0.426\end{array}$ & $\begin{array}{c}527,292 \\
0.419\end{array}$ & $\begin{array}{c}526,634 \\
0.421\end{array}$ & $\begin{array}{c}527,492 \\
0.427\end{array}$ \\
\hline \multicolumn{7}{|l|}{ C\&I Loans } \\
\hline$E P U_{t-\ell}$ & $\begin{array}{l}-13.59^{* * *} \\
(0.25)\end{array}$ & $\begin{array}{c}-15.18^{* * * *} \\
(0.34)\end{array}$ & $\begin{array}{l}-10.66^{* * *} \\
(0.29)\end{array}$ & $\begin{array}{l}-11.90^{* * *} \\
(0.38)\end{array}$ & $\begin{array}{c}-10.53^{* * *} \\
(0.33)\end{array}$ & $\begin{array}{l}-11.91^{* * *} \\
(0.43)\end{array}$ \\
\hline $\begin{array}{l}E P U_{t-\ell} \\
\times \text { Asset }_{i, t-\ell}\end{array}$ & & $\begin{array}{l}8.60^{* * *} \\
(1.07)\end{array}$ & & $\begin{array}{l}5.82^{* * *} \\
(1.07)\end{array}$ & & $\begin{array}{l}6.58^{* * *} \\
(1.07)\end{array}$ \\
\hline $\begin{array}{l}E P U_{t-\ell} \\
\times \text { Equity }_{i, t-\ell}\end{array}$ & & $\begin{array}{l}3.20^{* * *} \\
(0.38)\end{array}$ & & $\begin{array}{l}3.07^{* * *} \\
(0.38)\end{array}$ & & $\begin{array}{l}3.10^{* * *} \\
(0.37)\end{array}$ \\
\hline $\begin{array}{l}E P U_{t-\ell} \\
\times \operatorname{Cash}_{i, t-\ell}\end{array}$ & & $\begin{array}{l}-0.38 \\
(0.39)\end{array}$ & & $\begin{array}{l}-0.39 \\
(0.39)\end{array}$ & & $\begin{array}{l}-0.40 \\
(0.38)\end{array}$ \\
\hline $\begin{array}{l}E P U_{t-\ell} \\
\times \text { Securities }_{i, t-\ell}\end{array}$ & & $\begin{array}{l}-0.66^{* *} \\
(0.33)\end{array}$ & & $\begin{array}{l}-0.77^{* *} \\
(0.32)\end{array}$ & & $\begin{array}{l}-0.81^{* *} \\
(0.32)\end{array}$ \\
\hline Observations & 327,245 & 329,759 & 328,208 & 329,721 & 328,506 & 329,682 \\
\hline $\mathrm{R}^{2}$ & 0.250 & 0.244 & 0.251 & 0.246 & 0.252 & 0.247 \\
\hline
\end{tabular}

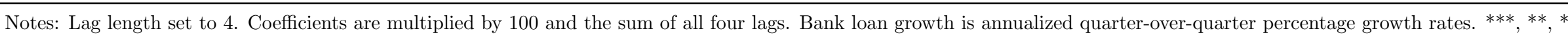

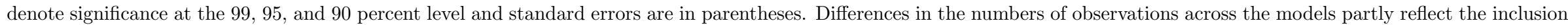
of time series controls and individual bank characteristics affect the number of unusual outliers screened out by the DFIT procedure used to limit the influence of outliers. 
Table 6: Effects of Post-1984 Aggregate Economic Policy Uncertainty (EPU1985) on Real Disaggregated Categories of Bank Level Loan Growth 1986 Q2 - 2014 Q3 (continued)

\begin{tabular}{|c|c|c|c|c|c|c|}
\hline Controls & Model 1: No controls & $\begin{array}{l}\text { Model 2: No controls, } \\
\quad \text { inter-actions }\end{array}$ & $\begin{array}{l}\text { Model 3: Non-regulatory } \\
\text { controls ( } \Delta \text { real GDP, } \Delta \\
\text { real fed funds rate) }\end{array}$ & $\begin{array}{c}\text { Model 4: } \\
\text { Non-regulatory } \\
\text { controls }(\Delta \text { real GDP, } \\
\Delta \text { real fed funds } \\
\text { rate), interactions }\end{array}$ & $\begin{array}{c}\text { Model 5: } \\
\text { Non-regulatory } \\
\text { controls \& regulatory } \\
\text { controls and } \\
\text { consumer sentiment } \\
\text { expectations }\end{array}$ & $\begin{array}{l}\text { Model 6: Non-regulatory } \\
\text { \& regulatory controls } \\
\text { and consumer sentiment } \\
\text { expectations, } \\
\text { interactions }\end{array}$ \\
\hline \multicolumn{7}{|l|}{ Real Estate } \\
\hline$E P U_{t-\ell}$ & $\begin{array}{l}-3.90^{* * *} \\
(0.08)\end{array}$ & $\begin{array}{l}-3.97^{* * *} \\
(0.08)\end{array}$ & $\begin{array}{l}-3.66^{* * *} \\
(0.09)\end{array}$ & $\begin{array}{l}-3.63^{* * *} \\
(0.09)\end{array}$ & $\begin{array}{l}-2.72^{* * *} \\
(0.10)\end{array}$ & $\begin{array}{l}-2.72^{* * *} \\
(0.10)\end{array}$ \\
\hline $\begin{array}{l}E P U_{t-\ell} \\
\times \text { Assets }_{i, t-\ell}\end{array}$ & & $\begin{array}{l}-2.31^{* * *} \\
(0.29)\end{array}$ & & $\begin{array}{l}-2.33^{* * *} \\
(0.29)\end{array}$ & & $\begin{array}{l}-2.35^{* * *} \\
(0.29)\end{array}$ \\
\hline $\begin{array}{l}E P U_{t-\ell} \\
\times \text { Equity }_{i, t-\ell}\end{array}$ & & $\begin{array}{l}1.18^{* * *} \\
(0.11)\end{array}$ & & $\begin{array}{l}1.18^{* * *} \\
(0.10)\end{array}$ & & $\begin{array}{l}1.19^{* * *} \\
(0.10)\end{array}$ \\
\hline $\begin{array}{l}E P U_{t-\ell} \\
\times \text { Cash }_{i, t-\ell}\end{array}$ & & $\begin{array}{l}-0.05 \\
(0.10)\end{array}$ & & $\begin{array}{l}-0.07 \\
(0.10)\end{array}$ & & $\begin{array}{l}-0.10 \\
(0.10)\end{array}$ \\
\hline $\begin{array}{l}E P U_{t-\ell} \\
\times \text { Securities }_{i, t-\ell}\end{array}$ & & $\begin{array}{l}0.30^{* * *} \\
(0.09)\end{array}$ & & $\begin{array}{l}0.32^{* * *} \\
(0.09)\end{array}$ & & $\begin{array}{l}0.28^{* * *} \\
(0.09)\end{array}$ \\
\hline $\begin{array}{l}\text { Observations } \\
\mathrm{R}^{2}, \text { corrected }\end{array}$ & $\begin{array}{c}521,716 \\
0.292\end{array}$ & $\begin{array}{c}525,442 \\
0.288\end{array}$ & $\begin{array}{c}523,798 \\
0.292\end{array}$ & $\begin{array}{c}525,656 \\
0.290\end{array}$ & $\begin{array}{c}524,406 \\
0.293\end{array}$ & $\begin{array}{c}525,860 \\
0.291\end{array}$ \\
\hline \multicolumn{7}{|l|}{ Consumer } \\
\hline$\overline{E P U_{t-\ell}}$ & $\begin{array}{l}-4.89^{* * *} \\
(0.10)\end{array}$ & $\begin{array}{l}-5.24^{* * *} \\
(0.11)\end{array}$ & $\begin{array}{l}-4.18^{* * *} \\
(0.11)\end{array}$ & $\begin{array}{l}-4.49^{* * * *} \\
(0.12)\end{array}$ & $\begin{array}{l}-4.90^{* * * *} \\
(0.13)\end{array}$ & $\begin{array}{l}-5.11^{* * *} \\
(0.141)\end{array}$ \\
\hline $\begin{array}{l}E P U_{t-\ell} \\
\times \text { Assets }_{i, t-\ell}\end{array}$ & & $\begin{array}{l}-1.55^{* * *} \\
(0.39)\end{array}$ & & $\begin{array}{l}-1.60^{* * *} \\
(0.38)\end{array}$ & & $\begin{array}{l}-1.64^{* * *} \\
(0.38)\end{array}$ \\
\hline $\begin{array}{l}E P U_{t-\ell} \\
\times \text { Equity }_{i, t-\ell}\end{array}$ & & $\begin{array}{l}0.77^{* * *} \\
(0.14)\end{array}$ & & $\begin{array}{l}0.77^{* * *} \\
(0.14)\end{array}$ & & $\begin{array}{l}0.76^{* * *} \\
(0.14)\end{array}$ \\
\hline $\begin{array}{l}E P U_{t-\ell} \\
\times \operatorname{Cash}_{i, t-\ell}\end{array}$ & & $\begin{array}{l}-0.10 \\
(0.14)\end{array}$ & & $\begin{array}{l}-0.11^{* *} \\
(0.13)\end{array}$ & & $\begin{array}{l}-0.11 \\
(0.13)\end{array}$ \\
\hline $\begin{array}{l}E P U_{t-\ell} \\
\times \text { Securities }_{i, t-\ell}\end{array}$ & & $\begin{array}{l}-0.04 \\
(0.12)\end{array}$ & & $\begin{array}{r}-0.111 \\
(0.12)\end{array}$ & & $\begin{array}{l}-0.08 \\
(0.12)\end{array}$ \\
\hline Observations & 492,335 & 497,151 & 494,289 & 497,003 & 494,899 & 497,027 \\
\hline $\mathrm{R}^{2}$ & 0.320 & 0.310 & 0.320 & 0.314 & 0.320 & 0.316 \\
\hline
\end{tabular}

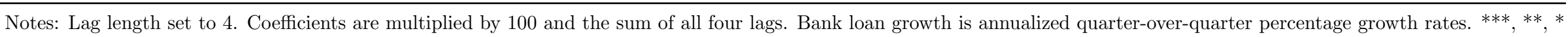

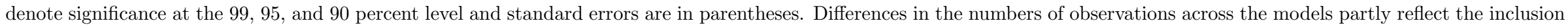
of time series controls and individual bank characteristics affect the number of unusual outliers screened out by the DFIT procedure used to limit the influence of outliers. 
Table 7: Effects of Post-1984 Financial Economic Policy Uncertainty on Real Disaggregated Categories of Bank Level Loan Growth 1986 Q2 - 2014 Q3

\begin{tabular}{|c|c|c|c|c|c|c|}
\hline Controls & Model 1: No controls & $\begin{array}{l}\text { Model 2: No controls, } \\
\quad \text { inter-actions }\end{array}$ & $\begin{array}{l}\text { Model 3: Non-regulatory } \\
\text { controls ( } \Delta \text { real GDP, } \Delta \\
\text { real fed funds rate) }\end{array}$ & $\begin{array}{c}\text { Model 4: } \\
\text { Non-regulatory } \\
\text { controls }(\Delta \text { real GDP, } \\
\Delta \text { real fed funds } \\
\text { rate), interactions }\end{array}$ & $\begin{array}{c}\text { Model 5: } \\
\text { Non-regulatory } \\
\text { controls \& regulatory } \\
\text { controls and } \\
\text { consumer sentiment } \\
\text { expectations }\end{array}$ & $\begin{array}{l}\text { Model 6: Non-regulatory } \\
\text { \& regulatory controls } \\
\text { and consumer sentiment } \\
\text { expectations, } \\
\text { interactions }\end{array}$ \\
\hline \multicolumn{7}{|l|}{ Total Loans } \\
\hline$E P U_{t-\ell}$ & $\begin{array}{l}-1.34^{* * *} \\
(0.02)\end{array}$ & $\begin{array}{l}-1.31^{* * *} \\
(0.02)\end{array}$ & $\begin{array}{l}-1.71^{* * *} \\
(0.03)\end{array}$ & $\begin{array}{l}-1.62^{* * *} \\
(0.03)\end{array}$ & $\begin{array}{l}-1.64^{* * *} \\
(0.04)\end{array}$ & $\begin{array}{l}-1.54^{* * *} \\
(0.04)\end{array}$ \\
\hline $\begin{array}{l}E P U_{t-\ell} \\
\times \text { Assets }_{i, t-\ell}\end{array}$ & & $\begin{array}{l}-1.27^{* * *} \\
(0.08)\end{array}$ & & $\begin{array}{l}-1.28^{* * *} \\
(0.08)\end{array}$ & & $\begin{array}{l}-1.30^{* * *} \\
(0.08)\end{array}$ \\
\hline $\begin{array}{l}E P U_{t-\ell} \\
\times \text { Equity }_{i, t-\ell}\end{array}$ & & $\begin{array}{l}0.36^{* * *} \\
(0.03)\end{array}$ & & $\begin{array}{l}0.37^{* * *} \\
(0.03)\end{array}$ & & $\begin{array}{l}0.37^{* * *} \\
(0.02)\end{array}$ \\
\hline $\begin{array}{l}E P U_{t-\ell} \\
\times \text { Cash }_{i, t-\ell}\end{array}$ & & $\begin{array}{l}-0.02 \\
(0.03)\end{array}$ & & $\begin{array}{l}-0.01 \\
(0.03)\end{array}$ & & $\begin{array}{l}0.00 \\
(0.03)\end{array}$ \\
\hline $\begin{array}{l}E P U_{t-\ell} \\
\times \text { Securities }_{i, t-\ell}\end{array}$ & & $\begin{array}{l}0.07^{* * *} \\
(0.02)\end{array}$ & & $\begin{array}{l}0.07^{* * *} \\
(0.02)\end{array}$ & & $\begin{array}{l}0.07^{* * *} \\
(0.02)\end{array}$ \\
\hline $\begin{array}{l}\text { Observations } \\
\mathrm{R}^{2}, \text { corrected }\end{array}$ & $\begin{array}{c}524,446 \\
0.415\end{array}$ & $\begin{array}{c}529,948 \\
0.419\end{array}$ & $\begin{array}{c}526,090 \\
0.419\end{array}$ & $\begin{array}{c}529,738 \\
0.423\end{array}$ & $\begin{array}{c}526,856 \\
0.421\end{array}$ & $\begin{array}{c}529,780 \\
0.425\end{array}$ \\
\hline \multicolumn{7}{|l|}{ C\&I Loans } \\
\hline$E P U_{t-\ell}$ & $\begin{array}{l}-4.25^{* * *} \\
(0.08)\end{array}$ & $\begin{array}{l}-4.02^{* * *} \\
(0.10)\end{array}$ & $\begin{array}{l}-3.89^{* * *} \\
(0.13)\end{array}$ & $\begin{array}{l}-3.60^{* * *} \\
(0.15)\end{array}$ & $\begin{array}{l}-3.54^{* * *} \\
(0.13)\end{array}$ & $\begin{array}{l}-3.10^{* * *} \\
(0.16)\end{array}$ \\
\hline $\begin{array}{l}E P U_{t-\ell} \\
\times \text { Assets }_{i, t-\ell}\end{array}$ & & $\begin{array}{l}-1.29^{* * *} \\
(0.34)\end{array}$ & & $\begin{array}{l}-1.77^{* * *} \\
(0.33)\end{array}$ & & $\begin{array}{l}-2.05^{* * *} \\
(0.33)\end{array}$ \\
\hline $\begin{array}{l}E P U_{t-\ell} \\
\times \text { Equity }_{i, t-\ell}\end{array}$ & & $\begin{array}{l}1.02^{* * *} \\
(0.13)\end{array}$ & & $\begin{array}{l}1.04^{* * *} \\
(0.13)\end{array}$ & & $\begin{array}{l}1.01^{* * *} \\
(0.13)\end{array}$ \\
\hline $\begin{array}{l}E P U_{t-\ell} \\
\times \operatorname{Cash}_{i, t-\ell}\end{array}$ & & $\begin{array}{r}-0.23^{*} \\
(0.13)\end{array}$ & & $\begin{array}{l}-0.18 \\
(0.13)\end{array}$ & & $\begin{array}{l}-0.13 \\
(0.13)\end{array}$ \\
\hline $\begin{array}{l}E P U_{t-\ell} \\
\times \text { Securities }_{i, t-\ell}\end{array}$ & & $\begin{array}{l}-0.09 \\
(0.11)\end{array}$ & & $\begin{array}{l}-0.11 \\
(0.10)\end{array}$ & & $\begin{array}{l}-0.05 \\
(0.10)\end{array}$ \\
\hline Observations & 328,214 & 332,412 & 328,468 & 331,863 & 328,938 & 331,824 \\
\hline $\mathrm{R}^{2}$ & 0.251 & 0.245 & 0.250 & 0.246 & 0.252 & 0.247 \\
\hline
\end{tabular}

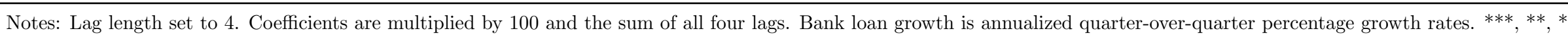

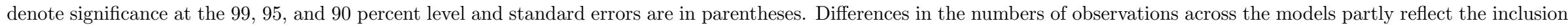
of time series controls and individual bank characteristics affect the number of unusual outliers screened out by the DFIT procedure used to limit the influence of outliers. 
Table 7: Effects of Post-1984 Financial Economic Policy Uncertainty on Real Disaggregated Categories of Bank Level Loan Growth 1986 Q2 - 2014 Q3 (continued)

\begin{tabular}{|c|c|c|c|c|c|c|}
\hline Controls & Model 1: No controls & $\begin{array}{l}\text { Model 2: No controls, } \\
\quad \text { inter-actions }\end{array}$ & $\begin{array}{l}\text { Model 3: Non-regulatory } \\
\text { controls ( } \Delta \text { real GDP, } \Delta \\
\text { real fed funds rate) }\end{array}$ & $\begin{array}{c}\text { Model 4: } \\
\text { Non-regulatory } \\
\text { controls ( } \Delta \text { real GDP, } \\
\Delta \text { real fed funds } \\
\text { rate), interactions }\end{array}$ & $\begin{array}{c}\text { Model 5: } \\
\text { Non-regulatory } \\
\text { controls \& regulatory } \\
\text { controls and } \\
\text { consumer sentiment } \\
\text { expectations }\end{array}$ & $\begin{array}{l}\text { Model 6: Non-regulatory } \\
\text { \& regulatory controls } \\
\text { and consumer sentiment } \\
\text { expectations, } \\
\text { interactions }\end{array}$ \\
\hline \multicolumn{7}{|l|}{ Real Estate } \\
\hline$\overline{E P U_{t-\ell}}$ & $\begin{array}{l}-1.39 * * * \\
(0.025)\end{array}$ & $\begin{array}{l}-1.42^{* * *} \\
(0.03)\end{array}$ & $\begin{array}{l}-1.87^{* * *} \\
(0.04)\end{array}$ & $\begin{array}{l}-1.86^{* * *} \\
(0.04)\end{array}$ & $\begin{array}{l}-1.55^{* * *} \\
(0.04)\end{array}$ & $\begin{array}{l}-1.53^{* * *} \\
(0.05)\end{array}$ \\
\hline $\begin{array}{l}E P U_{t-\ell} \\
\times \text { Assets }_{i, t-\ell}\end{array}$ & & $\begin{array}{l}-1.11^{* * *} \\
(0.10)\end{array}$ & & $\begin{array}{l}-1.13^{* * *} \\
(0.10)\end{array}$ & & $\begin{array}{l}-1.16^{* * *} \\
(0.10)\end{array}$ \\
\hline $\begin{array}{l}E P U_{t-\ell} \\
\times \text { Equity }_{i, t-\ell}\end{array}$ & & $\begin{array}{l}0.43^{* * *} \\
(0.04)\end{array}$ & & $\begin{array}{l}0.42^{* * *} \\
(0.04)\end{array}$ & & $\begin{array}{l}0.44^{* * *} \\
(0.04)\end{array}$ \\
\hline $\begin{array}{l}E P U_{t-\ell} \\
\times \operatorname{Cash}_{i, t-\ell}\end{array}$ & & $\begin{array}{l}0.01 \\
(0.04)\end{array}$ & & $\begin{array}{l}0.00 \\
(0.03)\end{array}$ & & $\begin{array}{l}0.02 \\
(0.03)\end{array}$ \\
\hline $\begin{array}{l}E P U_{t-\ell} \\
\times \text { Securities }_{i, t-\ell}\end{array}$ & & $\begin{array}{l}0.08^{* *} \\
(0.03)\end{array}$ & & $\begin{array}{l}0.09^{* * *} \\
(0.03)\end{array}$ & & $\begin{array}{l}0.10^{* *} \\
(0.03)\end{array}$ \\
\hline Observations & 522,848 & 529,006 & 524,092 & 528,185 & 524,812 & 528,251 \\
\hline $\mathrm{R}^{2}$, corrected & 0.291 & 0.284 & 0.291 & 0.287 & 0.293 & 0.290 \\
\hline \multicolumn{7}{|l|}{ Consumer } \\
\hline$E P U_{t-\ell}$ & $\begin{array}{l}-1.70 * * * \\
(0.03)\end{array}$ & $\begin{array}{l}-1.83^{* * *} \\
(0.04)\end{array}$ & $\begin{array}{l}-1.81^{* * *} \\
(0.05)\end{array}$ & $\begin{array}{l}-1.85^{* * *} \\
(0.06)\end{array}$ & $\begin{array}{l}-1.85^{* * *} \\
(0.06)\end{array}$ & $\begin{array}{l}-1.87^{* * *} \\
(0.06)\end{array}$ \\
\hline $\begin{array}{l}E P U_{t-\ell} \\
\times \text { Assets }_{i, t-\ell}\end{array}$ & & $\begin{array}{l}-1.02^{* * *} \\
(0.14)\end{array}$ & & $\begin{array}{l}-0.97^{* * *} \\
(0.13)\end{array}$ & & $\begin{array}{l}-1.00^{* * *} \\
(0.13)\end{array}$ \\
\hline $\begin{array}{l}E P U_{t-\ell} \\
\times \text { Equity }_{i, t-\ell}\end{array}$ & & $\begin{array}{l}0.36^{* * *} \\
(0.05)\end{array}$ & & $\begin{array}{l}0.38^{* * *} \\
(0.05)\end{array}$ & & $\begin{array}{l}0.39^{* * *} \\
(0.05)\end{array}$ \\
\hline $\begin{array}{l}E P U_{t-\ell} \\
\times \operatorname{Cash}_{i, t-\ell}\end{array}$ & & $\begin{array}{l}-0.08 \\
(0.05)\end{array}$ & & $\begin{array}{l}-0.08 \\
(0.05)\end{array}$ & & $\begin{array}{l}-0.06 \\
(0.05)\end{array}$ \\
\hline $\begin{array}{l}E P U_{t-\ell} \\
\times \text { Securities }_{i, t-\ell}\end{array}$ & & $\begin{array}{l}-0.02 \\
(0.04)\end{array}$ & & $\begin{array}{l}-0.01 \\
(0.04)\end{array}$ & & $\begin{array}{l}-0.01 \\
(0.04)\end{array}$ \\
\hline Observations & 493,227 & 500,683 & 494,708 & 499,754 & 495,169 & 499,504 \\
\hline $\mathrm{R}^{2}$ & 0.317 & 0.301 & 0.318 & 0.306 & 0.319 & 0.309 \\
\hline
\end{tabular}

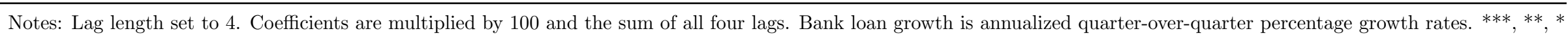

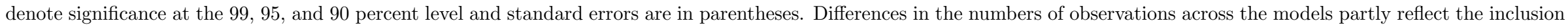
of time series controls and individual bank characteristics affect the number of unusual outliers screened out by the DFIT procedure used to limit the influence of outliers. 